Rafts in oligodendrocytes: Evidence and structure-function relationship Peer-reviewed author version

GIELEN, Ellen; Baron, W.; VAN DE VEN, Martin; STEELS, Paul; Hoekstra, D \& AMELOOT, Marcel (2006) Rafts in oligodendrocytes: Evidence and structure-function relationship. In: GLIA, 54(6). p. 499-512.

DOI: 10.1002/glia.20406

Handle: http://hdl.handle.net/1942/1376 


\section{Rafts in oligodendrocytes: evidence and structure-function relationship}

Ellen Gielen ${ }^{1}$, Wia Baron ${ }^{2}$, Martin vandeVen ${ }^{1}$, Paul Steels ${ }^{1}$, Dick Hoekstra ${ }^{2}$ and Marcel Ameloot ${ }^{1 *}$

\footnotetext{
${ }^{1}$ Biomedical Research Institute, Hasselt University and transnationale Universiteit Limburg, Agoralaan, Building D, B-3590 Diepenbeek, Belgium

${ }^{2}$ Department of Membrane Cell Biology, Faculty of Medical Sciences, University of Groningen, Groningen, The Netherlands
}

Running Title: Rafts in oligodendrocytes

Key words: myelin, microdomains, confined diffusion, axon-glial interaction

Abstract: 197 words

Text of the body: 6376 words

Number of figures: 3

Number of tables: 3

*Correspondence to: Marcel Ameloot, Hasselt University, Biomedical Research Institute, Laboratory of Cell Physiology, Agoralaan, gebouw D, B-3590 Diepenbeek, Belgium

Tel.: 00-32-11-26.85.46

Fax: 00-32-11-26.85.99

E-mail: marcel.ameloot@uhasselt.be 


\section{LIST OF ABBREVIATIONS}

Caspr1 contactin-associated protein, also known as paranodin

CGT ceramide galactosyl transferase

CHAPS 3-[(3-chloramidopropyl)-dimethylammonio]-1-propane-sulfonate

CNP 2',3'-cyclic nucleotide 3'-phosphodiesterase

CNS central nervous system

Cx32 connexin-32

DRM detergent-resistant membrane

EAE experimental allergic encephalitis

F3 contactin

FIIM fluorescence intensity imaging microscopy

GalC galactosylceramide

GPI-AP glycosylphosphatidylinositol-anchored protein

GSL glycosphingolipid

$\mathrm{mAb} \quad$ monoclonal antibody

MAG myelin-associated glycoprotein

MAL myelin and lymphocyte protein

$\mathrm{M} \beta \mathrm{CD} \quad$ methyl- $\beta$-cyclodextrin

MBP myelin basic protein

MDCK Madin-Darby canine kidney

MOBP myelin-associated oligodendrocytic basic protein

MOG myelin/oligodendrocyte glycoprotein

MS

NCAM 120 neuronal cell adhesion molecule of $120 \mathrm{kDa}$

NF155 $155 \mathrm{kDa}$ isoform of neurofascin

$\mathrm{NgR} \quad$ Nogo receptor

OLG oligodendrocyte

OMgp oligodendrocyte myelin glycoprotein

OPC oligodendrocyte progenitor cell

OSP oligodendrocyte-specific protein/claudin-11

PDGF platelet-derived growth factor

PLP proteolipid protein

Siglec sialic acid-dependent immunoglobulin-like family member lectin

SL sphingolipid

Src Rous sarcoma

TX-100 Triton X-100, t-octylphenoxypolyethoxyethanol 


\section{ABSTRACT}

The plasma membrane of eukaryotic cells exhibits lateral inhomogeneities, mainly containing cholesterol and sphingomyelin, which provide liquid-ordered microdomains (lipid 'rafts') that segregate membrane components. Rafts are thought to modulate the biological functions of molecules that become associated with them, and as such, they appear to be involved in a variety of processes, including signal transduction, membrane sorting, cell adhesion and pathogen entry. Although still a matter of ongoing debate, evidence in favor of the presence of these microdomains is gradually accumulating but a consensus on issues like their size, lifetime, composition and biological significance has yet to be reached. Here, we provide an overview of the evidence supporting the presence of rafts in oligodendrocytes, the myelin-producing cells of the central nervous system, and discuss their functional significance. The myelin membrane differs fundamentally from the plasma membrane, both in lipid and protein composition. Moreover, since myelin membranes are unusually enriched in glycosphingolipids, questions concerning the biogenesis and functional relevance of microdomains thus appear of special interest in oligodendrocytes. The current picture of rafts in oligodendrocytes is mainly based on detergent methods. The robustness of such data is discussed and alternative methods that may provide complementary data are indicated. 


\section{INTRODUCTION}

Oligodendrocytes (OLGs) are the myelin-producing cells of the central nervous system (CNS). They originate from mitotic and migratory precursors which go through discrete stages of maturation, i.e. from a pre-progenitor (precursor) cell, to a bipolar, migratory cell (O-2A, also called OLG progenitor cell (OPC)), a sulfatidepositive pre-OLG, an immature galactosylceramide (GalC)-positive OLG and finally to the mature, post-mitotic myelin-producing OLG (Figure 1) (Baumann and PhamDinh, 2001; Pfeiffer et al., 1993). The sequential steps in the maturation process of OLGs are characterized by the differential expression of developmental markers, which are recognized by specific monoclonal antibodies (mAbs) (Hardy and Reynolds, 1993).

Mature, myelin-producing OLGs extend a complex array of thin processes (Figure 2), which project outward from the cell body. Each process forms a segment of a highly specialized membrane that wraps around an axon, i.e. the myelin sheath. Architecturally, the myelin sheath is a complex membrane structure. While the cytoplasmic compartment is continuous from the OLG cell body to the myelin sheath, distinct membrane domains can be discerned which differ dramatically in lipid and protein composition (Figure 3). In the compact myelin region the cytoplasm has been virtually extruded. However, in the non-compact region (cytoplasmic incisures and abaxonal, periaxonal and paranodal loops) cytoplasm is still present. The protein fraction of purified myelin consists mainly (60 to 80\%) of proteolipid protein (PLP), its isoform DM20, and myelin basic protein (MBP) (Table 1). The primary function of these proteins is to stabilise the apposed myelin membranes in compact myelin (Table 2). Myelin and lymphocyte protein (MAL) and myelin-associated oligodendrocytic basic protein (MOBP) are also localized in compact myelin. The non-compact regions 
of myelin contain 2',3'-cyclic nucleotide 3'-phosphodiesterase (CNP), myelinassociated glycoprotein (MAG), myelin/oligodendrocyte glycoprotein (MOG), the $155 \mathrm{kDa}$ isoform of neurofascin (NF155), oligodendrocyte myelin glycoprotein (OMgp) and connexin-32 (Cx32) (Baumann and Pham-Dinh, 2001). A tight junctional array containing oligodendrocyte-specific protein/claudin-11 (OSP) marks the border between compact and non-compact myelin and may act as a diffusion barrier between these myelin subdomains (Bronstein et al., 2000; Gow et al., 1999; Krämer et al., 2001; Morita et al., 1999).

The ensheathment of axons with myelin is essential for the fast saltatory conduction of action potentials along the nerve cells and thus for the proper functioning of the nervous system. Abnormalities in myelin development or disturbance and destruction of its structure lead to severe neurological symptoms observed in diseases such as multiple sclerosis (MS) (Bartlett and Mackay, 1983; Baumann and Pham-Dinh, 2001; de Vries and Hoekstra, 2000). MS is the most common human demyelinating disease. It affects about $0.1 \%$ of the population in temperate climates (Wingerchuk et al., 2001). The disabling nature of MS strongly highlights the importance of OLGs. In addition to the initial elaboration of myelin, these cells are also required for the maintenance of the myelin sheath during adult life. As myelin is a compacted multilamellar membrane structure containing little cytoplasm, it is difficult to imagine how myelin membrane constituents are actively metabolized, recycled and/or reassembled. Nevertheless, during the lifespan of mice, individual myelin components are metabolized at different rates and the evidence suggests that these turnover rates are differently affected by aging (Ando et al., 2003). Maintenance of the functional myelin sheath during adult life would thus require a carefully regulated balance of myelin synthesis and turnover. 
Besides the subdivision of the fully mature myelin sheath into compact and noncompact myelin, the overall myelin membrane composition differs dramatically from that of the plasma membrane that surrounds the OLG cell body. Therefore, it is clear that the processes of myelin formation and maintenance require precise sorting and targeting mechanisms, which at least in part originate in the OLG cell body.

The myelin sheath, being strongly enriched in glycosphingolipids (GSLs), bears some resemblance to the apical membrane of polarized epithelial cells, whereas the OLG plasma membrane shows similarity to the basolateral membrane. Particularly in membranes enriched in GSLs and cholesterol, such as in apical membranes, GSL/cholesterol-enriched microdomains or so called 'lipid rafts' may exist and/or arise. These microdomains have been postulated to be involved in signaling and to act as targeting devices in the direct transport of apical proteins from the trans-Golgi network (TGN) to the apical membrane (Brown and Rose, 1992; Hoekstra et al., 2003; Ikonen and Simons, 1998; Ikonen, 2001; Simons and van Meer, 1988; Simons and Wandinger-Ness, 1990; Zurzolo et al., 1994). Given the enrichment of GSLs and cholesterol in myelin, it is tempting to consider that transport and functioning of myelin-specific proteins towards and in the myelin sheath are accomplished in a similar fashion.

In this review we will first critically discuss some aspects of the current concept of lipid rafts and subsequently provide an overview of the evidence that supports the presence and relevance of such microdomains in OLGs. The two main techniques used to study rafts in OLGs, detergent extraction and co-localization imaging, are discussed with respect to possible pitfalls. Alternative methods that can be used to study rafts in living cells are briefly described. 


\section{THE RAFT CONCEPT}

Although the cell membrane may be considered as a two-dimensional, liquid-like structure, it is far from being a homogeneous mixture of lipids and proteins (Jain and White, 1977; Karnovsky et al., 1982; Klausner et al., 1980; Lai, 2003). Rather, it is a non-ideal liquid mixture of molecules with variable degrees of mutual miscibility (Kusumi et al., 2004). As a consequence, the cell membrane contains a variety of molecular complexes and domains, characterized by different composition and spatial arrangement of the membrane-constituting lipids, which implies constraints on the diffusion of the membrane components (Kusumi et al., 2004; Lommerse et al., 2004; Mukherjee and Maxfield, 2004; Ritchie and Kusumi, 2004; Simons and Vaz, 2004; Vereb et al., 2003).

Lipid rafts are a particular class of membrane 'inhomogeneities', and they can be seen as relatively small 'liquid-ordered' membrane domains enriched in cholesterol, GSLs and phospholipids with saturated acyl chains. The lipids are ordered as in the gel phase but nevertheless remain mobile in the plane of the membrane, so that this phase has been denoted as the 'liquid-ordered' phase (Ahmed et al., 1997; Brown, 1998; Ipsen et al., 1987; Lentz et al., 1980; London, 2002; Schroeder et al., 1994; Simons and Toomre, 2000). Within these phases, specific lipids (and proteins) may dynamically associate with each other to form functionally relevant platforms that are important in processes as diverse as membrane protein sorting, signaling and (caveolae-mediated) endocytosis. An operational basis for this lateral functional compartmentalization was given by the discovery that a specific set of membrane components was insoluble in cold $\left(4^{\circ} \mathrm{C}\right)$ non-ionic detergent, toctylphenoxypolyethoxyethanol (Triton X-100, TX-100), resulting in a detergentresistant membrane (DRM) fraction that could be recovered by density gradient 
flotation (Brown and Rose, 1992; Brown and London, 2000; London and Brown, 2000; Simons and Ikonen, 1997). Resistance to detergent extraction has since become an operational definition of membrane rafts, and 'raft association' is defined as the partitioning of proteins and lipids into DRMs. Another criterion generally used to assign proteins to 'rafts' is the disruption of this association after cholesterol depletion. Cholesterol is an inherent part of such domains and its depletion by agents such as methyl- $\beta$-cyclodextrin $(\mathrm{m} \beta \mathrm{CD})$ ruptures the raft structure and, consequently, results in loss of the raft-associated function.

Compositional analysis of DRMs has provided a list of potential raft-associated molecules (Foster et al., 2003). However, the outcome of the detergent solubilization appears to depend on the cell type and the extraction condition (concentration, temperature) used (Banerjee et al., 1995; Chamberlain, 2004; Schuck et al., 2003). Moreover, detergent-resistance to solubilization also strongly depends on the nature of the detergent, which is thought to reflect in part the presence of microdomains of distinct composition.

The reliability of detergent resistance and cholesterol dependence as raft-supporting criteria has been subject of criticism (see last section). However, studies on living cells, using highly sophisticated approaches, corroborate the lipid raft hypothesis by demonstrating that 'raft' proteins exhibit cholesterol-dependent clustering at the plasma membrane, and display membrane-anchor dependent lateral diffusion rates only after dissociation from the raft structures (Friedrichson and Kurzchalia, 1998; Pralle et al., 2000; Varma and Mayor, 1998). Thus, although size and precise function of rafts may still be a matter of debate (Edidin, 2003), circumstantial evidence favors the presence of microdomains in the lateral plane of membranes. Pralle et al. (2000) estimated the presence per se and the size of rafts in eukaryotic cell membranes from 
local diffusion measurements of single GPI-anchored and transmembrane proteins, using a laser trap procedure. When associated with rafts, the diffusion rates were independent of the nature of the protein's association with the membrane. Dissolving rafts by cholesterol depletion accelerated the diffusion to rates as determined for nonraft associated membrane proteins. Moreover, the increase in diffusion rate of the initially raft-associated proteins appeared to be co-determined by the nature of the membrane anchor, GPI-linked proteins diffusing faster than transmembrane proteins (Pralle et al., 2000). Gaus et al. (2003) used two-photon microscopy to monitor the fluorescent membrane probe Laurdan (6-acyl-2-dimethylaminonaphthalene) in living cells. The so-called generalized polarization based on the environmental dependence of the fluorescence spectrum of Laurdan reflects the local organization of the surrounding lipids (gel, liquid-disordered and liquid-ordered phase). The distribution of generalized polarization values from a stack of images indicated the existence of different membrane phases in the living cell. Their relative coverage was sensitive to cholesterol depletion agents (Gaus et al., 2003).

Depending on the time-resolution of the technique used, different properties can be revealed (Kusumi et al., 2004). Rafts are dynamic so that proteins and lipids can move in and out. Resting cells may contain "reserve rafts", which are postulated to be sufficiently small (down to only 3 molecules, detectable by the sphingomyelinbinding protein earthworm toxin, lysenin; Kiyokawa et al., 2005) and short-lived (lifetimes on the order of a few microseconds; Kusumi et al., 2004) to allow for rapid diffusion of its "transient" constituent molecules to quickly reach the site of signal input. Ligand binding and cross-linking of raft-preferring molecules could induce "receptor-clustered rafts". These larger and stabilized rafts are thought to have a sufficient size and lifetime (up to 1-10h) to facilitate the incorporation of various key 
signaling molecules which in turn may result in downstream signaling (Brown and London, 1998; Brown and London, 2000; Kusumi et al., 2004; Kusumi et al., 2005; Mukherjee and Maxfield, 2004; Simons and Ikonen, 1997).

\section{RAFTS AND MYELIN FORMATION}

As early as in 1989, it was postulated that sorting and trafficking of PLP, the major myelin protein in the CNS, is coupled to that of myelin GSLs (Pasquini et al., 1989). Evidence for a common transport route came from observations in isolated brain slices that the inhibition of GSL synthesis reduced the translocation of PLP into myelin by about $50 \%$, while the incorporation of MBP and overall protein synthesis were unaffected (Pasquini et al., 1989). In subsequent work, sulfatide was identified to be co-transported with PLP (Brown et al., 1993), although this GSL species largely resides in the plasma membrane of the OLG cell body rather than in the myelin membrane, which is strongly enriched in GalC. However, others (Bansal and Pfeiffer, 1994; van der Haar et al., 1998) demonstrated in primary OLG cell cultures that an inhibition of sulfation did not affect PLP transport to processes and sheets in these cells. Moreover, when expressed in GalC- and sulfatide-deficient CHO (Chinese hamster ovary) cells, PLP-delivery to the plasma membrane was unaffected compared to such delivery in cells expressing these SLs, whereas PLP was found to be fully soluble in TX-100. Taken together these data suggest that transport of PLP to the OLG membrane does not involve a raft-mediated sorting system (Kim and Pfeiffer, 1999; Krämer et al., 1997; van der Haar et al., 1998). It is possible however that the apparent controversy may originate from differences in cell systems, the early work having been carried out in tissue, while the latter studies were performed in primary cell cultures. In a culture dish, in the absence of neurons, there are no cell-cell (axon- 
glial) or cell-matrix contacts. However, OLGs in monoculture do differentiate and form flat myelin networks, called myelin sheets. They may not fully mature and compaction of the myelin sheath does not occur. By contrast, in vivo (and possibly in OLG-neuron co-cultures) the fully mature myelin sheath is further segregated in compact and non-compact myelin. Transport mechanisms used by developing OLGs in vitro might therefore differ from those used during the maintenance stage of the fully mature myelin sheath. Thus, in vivo, PLP may reside in different myelin fractions and, depending on its localization, may only partly solubilize in TX-100, as is the case in myelin of adult mice where PLP is partly TX-100 resistant (Saravanan et al., 2004). Evidently, further work in vitro, using mixed brain cultures as well as careful fractionation of in vivo brain slice material, should clarify this issue.

More recently, it has become clear that detergent-resistant microdomains do not necessarily have to be defined exclusively by their insolubility in TX-100. Rather, such fractions can also be isolated by gradient flotation following extraction with other non-ionic detergents such as Lubrol, Brij 98, 3-[(3-chloramidopropyl)dimethylammonio]-1-propane-sulfonate (CHAPS), etc. When OLGs are extracted with CHAPS, PLP is recovered in the DRM fraction and indeed behaves as a raftassociated protein (Simons et al., 2000). On the other hand, the glycosylphosphatidylinositol-anchored proteins (GPI-APs) NCAM 120 (neuronal cell adhesion molecule of $120 \mathrm{kDa}$ ) and F3 (also known as contactin) are soluble in CHAPS but highly enriched in TX-100-insoluble fractions (Simons et al., 2000). This led to the conclusion that PLP may assemble into a specialized "myelin-raft", which directs sorting and trafficking of myelin components (Simons et al., 2000). Interestingly, as NCAM 120 resides in the plasma membrane of the cell body whereas F3 localizes to the sheet, these data suggest that, based on detergent-resistence of PLP 
versus F3, different DRMs coexist in the myelin sheet. These findings would favor the notion (Brügger et al., 2004; Madore et al., 1999) that the disparate results obtained by different detergents may relate to the co-existence of different domains, characterized by differences in composition. However, claims have been made that differential insolubility of proteins in different detergents is not sufficient to imply their association with distinct lipid rafts (Chamberlain, 2004; Pike, 2004).

From a functional point of view, the specific association of a given molecular compound with a DRM has been correlated with sorting and, in polarized epithelial cells, with apical-directed membrane transport (Hoekstra et al., 2003; Ikonen and Simons, 1998; Ikonen, 2001; Simons and van Meer, 1988; Simons and WandingerNess, 1990; Zurzolo et al., 1994). As noted above and elsewhere (de Vries and Hoekstra, 2000), OLGs can also be considered to be polarized, given the remarkable differences in lipid composition of plasma and myelin membrane, the latter being particularly enriched in GSLs, saturated phospholipids and cholesterol, a composition typical of raft-like domains. Remarkably, when the trafficking of the viral membrane proteins influenza haemagglutinin (HA) and vesicular stomatitis virus $\mathrm{G}$ protein (VSVG) were monitored in infected OLGs, HA was expressed at the plasma membrane of the cell body, where it localizes in a TX-100 detergent-resistant fraction, while VSVG is transported to the sheet as a TX-100 soluble protein (de Vries et al., 1998). When expressed in polarized epithelial cells, HA and VSVG are sorted and transported to the apical and basolateral surface, respectively. Using these findings as criteria, it can be suggested that the myelin membrane is target of a basolateral-like mechanism, while the plasma membrane displays apical-like features. Consistent with this notion is the observation that the t-SNARES (target-membrane-associated soluble $\mathrm{N}$-ethylmaleimide fusion protein attachment protein (SNAP) receptor) syntaxin-3 and 
syntaxin-4 similarly distribute in a polarized manner, syntaxin-3 being localized at the plasma membrane, while syntaxin-4 is strongly enriched in the sheet (Klunder and Hoekstra, personal communication). Alternatively, Kroepfl and Gardinier (2001) stably transfected (polarized) Madin-Darby canine kidney (MDCK) cells with the myelin proteins MOG, PLP and MAG, and subsequently examined the membrane targeting of these myelin proteins. As in OLGs, MOG and PLP were sorted to mutually exclusive compartments in MDCK cells. MOG, a non-compact myelin protein, was solely found in the basolateral membrane, whereas PLP, a compact myelin protein, was exclusively found within the apical membrane (Kroepfl and Gardinier, 2001). Whether such data can be extrapolated to oligodendrocytes in terms of basolateral versus apical sorting mechanisms remains to be determined. As noted, in the same cells, HA is specifically sorted to the apical membrane, but when expressed in OLGs its localization is largely restricted to the cell body plasma membrane. MAL, present in both epithelial cells and OLGs, is sorted to the apical membrane and into the sheath in TX-100 detergent-insoluble microdomains, in contrast to PLP, which is soluble in this detergent. Together, these data emphasize the complexity in directly comparing the role of detergent-resistence in apical versus basolateral sorting, and extrapolation of polarized sorting in epithelial cells to that in OLGs.

Indeed in several recent studies (Paladino et al., 2004; Slimane et al., 2003) it has become clear that microdomain or raft-mediated transport, as defined by detergentresistence, is not restricted to apical membrane directed trafficking, but is similarly operational in basolateral transport pathways. Accordingly, formation of different raft domains might be a mechanism of membrane subdomain organization, important for compartmentalization of signaling molecules as well as for the sorting of myelin 
components. Whether the distinction that many of the major myelin-specific proteins display different preferences for localization in microdomains, as reflected by differences in detergent solubility (Table 3), coincides with differences in sorting/transport mechanisms, remains to be elucidated. For this, further analyses including pulse-chase experiments and OLG development-dependent transport studies rather than determination of a detergent-resistent localization at steady state are necessary. This notion also relates to the potentially distinct distribution of a myelin protein in fully mature OLGs, where it may partition in both compact and noncompact myelin, thus possibly displaying distinct detergent-solubility properties which, moreover, do not necessarily have to correlate with those in its sheet-directed transport. Thus the dynamics and transient association of proteins in distinct rafts should be particularly taken into account when investigating their association with membrane microdomains.

Thus far, the picture of molecular parameters involved in DRM-mediated sorting is far from complete. In apical sorting pathways, the formation of high-molecularweight complexes as part of the mechanism of DRM recruitment seems to be required (Helms and Zurzolo, 2004; Paladino et al., 2004; Schuck and Simons, 2004; Zurzolo et al., 2003). Oligomerization or association with a high-molecular-weight complex might lead to an exponential increase in raft affinity with increasing oligomer size (Simons and Vaz, 2004), thereby stabilizing raft association. In addition, oligomerization might cause the coalescence of small rafts into a stable functional sorting domain or signal. Are such mechanisms operational in OLGs? One protein that might promote raft clustering is MAL, which is also known as MVP17 (myelin vesicular protein 17; Kim et al., 1995) and VIP17 (vesicular integral protein 17; Zacchetti et al., 1995). MAL is a $17 \mathrm{kDa}$ non-glycosylated integral membrane protein 
that localizes in the Golgi (Puertollano et al., 1999) and is required for apical targeting in epithial cells (Cheong et al., 1999; Martin-Belmonte et al., 2000; Puertollano et al., 1999). In OLGs, MAL has been shown to be a component of GSL-rafts (Frank et al., 1998; Frank, 2000; Kim et al., 1995; Kim and Pfeiffer, 2002; Schaeren-Wiemers et al., 1995) and to end up in compact myelin (Frank et al., 1998). MAL is upregulated during active myelination (Kim et al., 1995; Schaeren-Wiemers et al., 1995). In addition, MAL can form oligomers, which might function to cluster rafts at the sites at which sorting takes place (Schuck and Simons, 2004). However, MAL is relatively late expressed in myelinogenesis, i.e., after expression of most major myelin proteins, including PLP. Whether the role of MAL is thus restricted to the reorganization of myelin proteins in compact myelin or is involved in sorting and transport during maintenance of the myelin sheath, remains to be determined. In this context it is worthwhile to mention that, based on observations in MAL-deficient mice, MAL has recently been implicated in the maintenance of axon-glial interactions at the CNS paranodes, presumably by playing a role in the trafficking and/or sorting of paranodal proteins NF155 and MAG (Schaeren-Wiemers et al., 2004).

\section{RAFTS IN AXON-GLIAL INTERACTION}

Myelination of axons by OLGs involves recognition of the axonal surface, subsequent interaction between the OLG and the axon, spiral enwrapment of the axonal segment and finally compaction of the multilamellar OLG membrane into a functional myelin sheath (Sherman and Brophy, 2005, and references therein). There is substantial evidence that microdomain assembly is a prerequisite for proper recruitment of the molecular machinery involved in axon-glial interaction. 


\section{Initial axon-glial contact}

Fyn is a key molecule in OLG differentiation and myelination (Osterhout et al., 1999; Sperber and McMorris, 2001; Umemori et al., 1994). This molecule belongs to the Src (Rous sarcoma) family of kinases and is associated with cell migration, proliferation, differentiation, adhesion, apoptosis and cytoskeletal rearrangements (Osterhout et al., 1999). Fyn is associated with the F3/contactin adhesion protein in OLGs and this interaction occurs within rafts (Krämer et al., 1999). Since antibody-mediated crosslinking of F3/contactin in the oligodendroglial cell line Oli-neu results in activation of Fyn kinase (Krämer et al., 1999), the functional advantage of being localized in a microdomain thus becomes readily apparent, i.e., providing an environment for molecular clustering which triggers an efficient signal transduction between axons and OLGs in the early phases of myelination. Activation of this pathway causes Fyn to bind to the cytoskeletal proteins Tau, which further strengthens initial axon-glial contact, and $\alpha$-tubulin in OLGs. It is thought that the local reorganization of the cytoskeleton, accomplished in this manner, might subsequently facilitate directed transport of myelin-specific lipids and proteins to the expanding myelin sheath (Klein et al., 2002).

\section{Myelin integrity}

The functional role that raft domains may play in establishing axon-glial interactions is further supported by observations that NF155, an ankyrin-binding cell adhesion molecule, also localizes in such microdomains, which seems necessary for carrying out its function. NF155 is localized within the paranodal loops where it interacts with the Caspr1 (contactin-associated protein, also known as paranodin)-F3/contactin protein complex on the axon (Charles et al., 2002; Tait et al., 2000), an interaction that is required for myelination in co-cultures of OLGs and neurons (Charles et al., 
2002). The finding that NF155 is completely absent from paranodes of CGT (ceramide galactosyl transferase) knockout mice (Menon et al., 2003) indicates that raft assembly might be critical for the accumulation of NF155 in paranodes. CGT is the key enzyme of the galactolipid biosynthesis pathway and myelin of mice missing the CGT enzyme completely lacks GalC and sulfatide (Bosio et al., 1996; Lee, 2001). Recently, it has been shown that NF155 associates with DRMs (rafts) in the CNS (Schaeren-Wiemers et al., 2004) and that this association is commensurate with the timing of paranode formation (Schafer et al., 2004). Given the abnormal structure of the paranodal loops in CGT knockout mice (Bosio et al., 1998), it is likely that the correct membrane association of NF155 is important for the stability of the paranodal structure and thus for the integrity of the myelin sheath. During myelination, close contact between the axon and the OLG will lead to interaction between NF155 and Caspr1-F3/contactin, which in turn will stabilize these proteins and the lipid environment in which they reside, providing a "nucleation" site for the formation of a lipid raft protein adhesion complex. Additional NF155, Caspr and F3/contactin might be recruited because of an increased affinity for the raft environment, which in turn leads to further stabilization through the axon-glial interaction. The sum of these protein-protein interactions within the raft environment would provide the basis for the strong adhesion complex at the paranode and thus for myelination and myelin integrity. Of relevance to potential causes of a demyelinating disease could thus be that an interference with raft stability/association might result in destabilization of the axon-glial interaction and eventually lead to demyelination. Culturing OLGs on fibronectin, which mimics changes in the extracellular matrix (ECM) as occurs in MS due to the perturbation of the blood brain barrier (BBB), results in dissociation of NF155 from the DRM fraction as well as in inhibition of the morphological 
differentiation of OLGs (Maier et al., 2005). Consistent with in vitro data, raft association of NF155 is substantially reduced in spinal cord of experimental allergic encephalitis (EAE) rats, an animal model for the demyelinating disease MS. Hence, the association of NF155 to microdomains in the myelin membrane is required for its participation in intermolecular interactions, which are important for myelination and myelin integrity.

\section{Raft-mediated adverse effects}

Interestingly, the association of MOG with microdomains seems to induce process retraction rather then stabilizing myelin integrity. MOG is an integral myelin-specific protein, which is localized in the outer lamella of the myelin sheath and therefore exposed to the extracellular environment. Although MOG is only a minor component of the myelin membrane (0.01- $0.05 \%$ of the total myelin protein content), it induces severe EAE after administration to both rodents and primates (Iglesias et al., 2001; Johns and Bernard, 1999). Furthermore, injection of mAbs against MOG into rodents causes extensive myelin destruction in situ (Linington et al., 1988). In addition, antiMOG antibodies are found in the cerebrospinal fluid and in lesions of acute MS patients (Linington and Lassmann, 1987; Reindl et al., 1999). Therefore, it appears that MOG/anti-MOG interactions could be mediators in the process of demyelination in EAE and MS. The role of MOG in this process is closely related to its dynamic association with DRMs, which causes activation of distinct signal transduction pathways. Following Ab binding, the non-raft associated fraction causes the activation of mitogen-activated protein kinase (MAPK) and Akt pathways. When present in TX100 insoluble rafts, signaling pathways related to stress response and cytoskeletal instability are activated, which result in the retraction of OLG processes (Marta et al., 2003; Marta et al., 2005). Worth noting is that MOG-mediated retraction of OLG 
processes requires a secondary cross-linking antibody. The role of this secondary cross-linking antibody might be to increase raft affinity and to promote stabilization of MOG in rafts with a lifetime that suffices to recruit the signaling molecules necessary for process retraction. In MS, macrophages and complement could mimic the effect of the secondary cross-linking antibody since they are able to bind IgG (immunoglobulin G) molecules. In fact, a secondary cross-linking antibody might not be necessary when polyclonal anti-MOG antibodies with different epitope specificity are present in MS patients.

\section{Dual functions mediated through rafts}

Like the NF155-Caspr1-F3/contactin interaction, the interplay of MAG with its axonal receptors might also occur by raft-mediated intercellular interactions between OLGs and neurons. MAG, a quantitatively minor protein of myelin $(<1 \%)$, serves both as a myelin-stabilizing factor and as inhibitor of nerve regeneration (Vyas and Schnaar, 2001; Weiss et al., 2000). It is a sialic acid-binding protein of the siglec (sialic acid-dependent immunoglobulin-like family member lectin) family. MAG is restricted to the periaxonal membrane of the myelin sheath where it interacts with molecules on the axonal membrane, including the gangliosides GD1a and GT1b (Vinson et al., 2001; Vyas et al., 2002) and the GPI-linked Nogo receptor (NgR) (Domeniconi et al., 2002; Fournier et al., 2001; Liu et al., 2002). As the affinity of a monomeric siglec molecule (e.g. MAG) for its sialic acid ligand is thought to be relatively low, the rationale for localization of MAG and its receptors in lipid rafts might be the creation of discrete areas of high local molecular density necessary for the activation of signaling pathways in both cell types. In neurons, this interaction would result in the inhibition of neurite outgrowth, whereas in OLGs it would be necessary for the maintenance of myelin integrity (Vinson et al., 2003). MAG was 
found to interact with lipid rafts on the surface of neurons, which contain known binding partners of MAG, namely GT1b and NgR, as well as p75 and Rho. The latter are required for transmitting MAG-mediated signals into neurons. Interestingly, in primary OLGs, antibody-induced cross-linking of MAG causes the (re-)partitioning of the protein from a soluble into a DRM fraction (Marta et al., 2004). Cross-linking apparently seems to induce recruitment into rafts and the observed clustering thus results from the cross-linking as such rather than from the coalescence of individual, MAG containing rafts.

\section{ON A FUNCTIONAL ROLE OF RAFTS IN OLIGODENDROCYTE BEHAVIOR}

Raft recruitment and coalescence of rafts may provide OLGs with a means for differential regulation of growth factor responses during development. Plateletderived growth factor (PDGF), for example, does not only regulate OPC proliferation but also survival (Calver et al., 1998). The nature of the response to PDGF, proliferation or survival, is determined by the identity of the integrin associated with the PDGF $\alpha$ receptor (PDGF $\alpha \mathrm{R})$. $\alpha \mathrm{v} \beta 3$, which stimulates proliferation, interacts with the PDGF $\alpha \mathrm{R}$ in OLG precursors (Baron et al., 2002), while $\alpha 6 \beta 1$, which is involved in cell survival (Colognato et al., 2002) and myelination (Relvas et al., 2001), is found to be the interaction partner in immature Galc-positive OLGs (Baron et al., 2003). Rafts could contribute to integrin signaling by facilitating growth factor receptorintegrin interactions necessary to trigger integrin activation by concentrating the necessary complex of signaling molecules required for activation and/or down-stream signaling. Alternatively, the conformational equilibrium between inactive and active integrins might be displaced in favor of the activated integrin by the altered membrane 
structure of the lipid raft (ffrench-Constant and Colognato, 2004). Activation of integrins is associated with a change from a bent to an extended conformation, with associated intramolecular interactions altering the conformation of the ligand-binding pocket, thereby increasing ligand affinity (Baron et al., 2005, and references therein). The OLG PDGF $\alpha$ R becomes associated with lipid rafts at a stage when it no longer promotes proliferation but instead is required for survival (Baron et al., 2003). A pool of integrin $\alpha 6 \beta 1$ is also present in membrane rafts, but these are different from the PDGFaR-containing rafts. Laminin-2, which is expressed on axons of the CNS (Colognato et al., 2002), induces coalescence of the integrin $\alpha 6 \beta 1^{+}$rafts with the $\mathrm{PDGF}_{\mathrm{R}} \mathrm{R}^{+}$lipid rafts, resulting in receptor co-association, integrin activation, affinity modulation and signal amplification at physiological PDGF levels, respectively, ultimately leading to survival of the OLGs (Baron et al., 2003; Decker and ffrenchConstant, 2004; Decker et al., 2004). Merging of PDGF $\alpha$ R-containing microdomains with those that contain the integrin $\alpha 6 \beta 1$ could thus provide a distinct signalling microenvironment that allows the PDGF signaling response during OLG development to switch from proliferation to survival. Fyn and Lyn (another member of the Src kinase family) were recently shown to be key effector molecules within the integringrowth factor receptor complexes that selectively promote either proliferation or differentiation/survival (Colognato et al., 2004). As discussed earlier, Fyn has been postulated to play a role in OLG differentiation and myelin formation (Klein et al., 2002; Krämer et al., 1999). Lyn, on the other hand, is associated with the PDGF $\alpha$ R$\alpha \mathrm{v} \beta 3$ integrin complex and contributes to proliferation signaling (Colognato et al., 2004). After axonal contact, Lyn dissociates from the integrin-growth factor complex whereas Fyn is activated thereby promoting OLG survival, differentiation and myelin formation (Colognato et al., 2004). 


\section{RAFT ANALYSIS: CRITICAL HINDSIGHT AND FUTURE PERSPECTIVES}

The formation of lipid rafts in OLGs seems to be a mechanism of membrane subdomain organization, important for compartmentalization of signaling molecules as well as for the sorting of myelin components. However, all the information available at present about the existence and possible function of lipid rafts in OLGs is mainly based on detergent extraction. Different detergents, extraction procedures and cell/tissue sources have been used (Table 3). As already indicated by others (Banerjee et al., 1995; Chamberlain, 2004; Edidin, 2001a; London and Brown, 2000; Schuck et al., 2003), the detergent insolubility of proteins depends highly on the detergent and the extraction conditions used. DeBruin et al. (2005) used three different detergents (TX-100, CHAPS and Brij 96V) to characterize membrane microdomains in developing and mature bovine myelin. Taylor et al. (2002) screened four different detergents (under four extraction conditions) to determine which supported the retention of four integral (MAG, OSP/claudin-11, MOG and PLP) and three peripheral (NCAM-120, CNP and MBP) proteins of the myelin membrane in a lowdensity DRM fraction. Both groups reported that the amount of proteins and lipids, as well as the sucrose gradient buoyancy of the DRM-complexes, varied substantially among the detergents and extraction procedure used.

In addition to the detergent dependence of the results, it is not clear whether proteins found to be present in DRMs were associated with lipid rafts in the living cell as detergent extraction seems to dramatically alter the lipid composition of preexisting domains (de Almeida et al., 2003; Heerklotz, 2002; Heerklotz et al., 2003; Skwarek, 2004). However, others provide evidence that isolation of DRM from biological membranes by detergent-induced extraction is not an artefact (Staneva et al., 2005). 
Different detergents differ in structure, which results in differential partitioning into the plasma membrane and the disruption of specific protein-lipid and protein-protein interactions by individual detergents. In addition, individual detergents have a different ability to deplete inner leaflet lipids. TX-100, for example, selectively extracts inner leaflet lipids giving rise to membrane preparations with a preponderance of outer leaflet lipids, whereas Brij 98-resistant rafts have a normal balance of inner and outer leaflet lipids (Pike et al., 2005). It is unlikely that different detergents reflect the same aspects of membrane organization. In a complex environment as the cell membrane, DRM association may at best serve to define a circumstantial steady-state biochemical characteristic. It cannot provide reliable information regarding the preexisting molecular organization on the multicomponent cell surface. This underscores both the structural complexity of cell membranes and the need for additional approaches to understand their architecture and in particular the dynamics of that architecture. Detergent extraction only reflects information concerning the steady-state but does not yield any information about dynamic events, which may influence the recruitment of molecules into lipid rafts. As mentioned before, cross-linking induces the relocalization of certain proteins, e.g. MOG, into DRM domains (Marta et al., 2003, 2005). The relocalization of MOG within microdomains, however, is a reversible event, and is abolished after removal of the cross-linking antibody. The effective partitioning of a given protein in such domains could vary, reflected by differences in the fraction recovered, using a given detergent, or by differences in detergent-dependent solubilization. Hence, extraction per se may also not properly reflect the functional relevance of localization of a protein in a particular microdomain, since at steady-state the protein is likely not restricted to one domain only. Knowledge about the dynamic behaviour of membrane architecture, 
however, may in turn determine the molecular composition of a microdomain and hence its biophysical properties, including the lifetime.

The method of cholesterol depletion seems to be rather controversial as well. Acute cholesterol depletion blocks both endo- and exocytosis, alters the actin cytoskeleton and inhibits lateral diffusion of membrane proteins. A number of pleiotropic effects may thus result, including the dissociation of various proteins from lipid rafts (Edidin, 2003; Lai, 2003). Biochemical approaches should be combined with other methods that could identify lipid rafts in intact cell membranes and provide information about the size, lifetime, dynamics and functional role of rafts in living cells.

Fluorescence intensity imaging microscopy (FIIM) is commonly used to determine the distribution and possible co-localization of putative raft markers labelled with different fluorescent conjugated antibodies. A physical limitation of FIIM methods is the optical resolution (airy disk diameter) of $\sim 250 \mathrm{~nm}$, which makes the resolvable detail related to the pixel size larger than the size of the rafts (Kusumi and Suzuki, 2005; Pralle et al., 2000). The observation of co-localization, although required, is therefore insufficient to conclude that the labeled components are within the same raft. The co-localization imaging approach has a limited time resolution so that restricted information, if any, about the kinetic properties of the domains can be obtained. The problem of the restricted spatial resolution can be circumvented by the application of Förster resonance energy transfer (FRET) (Acasandrei et al., 2006; Kenworthy and Edidin, 1998; Kenworthy and Edidin, 1999; Rao and Mayor, 2005). In order to obtain information about the kinetic properties of molecules, methods such as single particle tracking (SPT) and photonic force microscopy (Lommerse et al., 2004; Pralle et al., 2000) can be used. Diffusional mobility can also be measured at single-molecule sensitivity by fluorescence correlation spectroscopy (FCS). It was 
recently demonstrated that FCS promises to be a valuable tool to elucidate lipid raft associations both in domain-exhibiting model membranes and in cell membranes (Bacia et al., 2004; Wawrezinieck et al., 2005). Moreover, a first attempt has been made to study the membrane heterogeneity of living OLN-93 oligodendroglial cells by means of one-photon FCS (Gielen et al., 2005; Humpolíčková et al., 2006). Fluorescence recovery after photobleaching (FRAP) is another technique that can be used to determine the translational mobility of fluorescent molecules in the cell membrane (Kenworthy et al., 2004; Lippincott-Schwartz et al., 2003; Phair and Misteli, 2001).

A major advantage of the described microfluorimetric techniques in comparison to detergent extraction is that they can be applied to single cells so that only tiny amounts of valuable brain tissue are required for these experiments. Other techniques that can be used to study rafts in intact cell membranes are electron microscopy (EM: Prior et al., 2003; Wilson et al., 2000), atomic force microscopy (AFM: Giocondi et al., 2004; Henderson et al., 2004; Rinia et al., 2001; Yuan et al., 2002) and near-field scanning optical microscopy (NSOM: Dunn, 1999; Edidin, 2001b).

The different techniques described above characterize rafts on different time and spatial scales (Edidin, 1997; Kenworthy 2005; Lagerholm et al., 2005; Lommerse et al., 2004; Mátko and Szöllõsi, 2002), yielding a wide range of characteristic parameter values for lipid rafts in terms of size, stability and abundance (Lommerse et al., 2004). This clearly emphasizes the need to combine several techniques to assess detailed information about the size, structure and function of lipid rafts. Techniques, such as FRAP, FCS, FRET and SPT allow the investigation of membrane heterogeneity in living cells under physiological conditions. The combination of biochemical studies with these photophysical, microfluorimetric methods will yield a 
better insight in the biological relevance of rafts in OLGs and help to come to a consensus on lipid rafts concerning their existence, size, lifetime and molecular organization. 


\section{REFERENCES}

Acasandrei MA, Dale RE, vandeVen M, Ameloot M. 2006. Two-dimensional Förster resonance energy transfer (2-D FRET) and the membrane raft hypothesis. Chem Phys Lett 419:469-473.

Ahmed SN, Brown DA, London E. 1997. On the origin of sphingolipid/cholesterol-rich detergentinsoluble cell membranes: physiological concentrations of cholesterol and sphingolipid induce formation of a detergent-insoluble, liquid-ordered lipid phase in model membranes. Biochem 36: 10944-10953.

Ando S, Tanaka Y, Toyoda Y, Kon K. 2003. Turnover of myelin lipids in aging brain. Neurochem Res 28:5-13.

Bacia K, Scherfeld D, Kahya N, Schwille P. 2004. Fluorescence correlation spectroscopy relates rafts in model and native membranes. Biophys J 87:1034-1043.

Banerjee P, Joo JB, Buse JT, Dawson G. 1995. Differential solubilization of lipids along with membrane proteins by different classes of detergents. Chem Phys Lipids 77:65-78.

Bansal R, Pfeiffer SE. 1994. Inhibition of protein and lipid sulfation in oligodendrocytes blocks biological responses to FGF-2 and retards cytoarchitectural maturation, but not developmental lineage progression. Dev Biol 162:511-524.

Baron W, Colognato H, Ffrench-Constant C. 2005. Integrin-growth factor interactions as regulators of oligodendroglial development and function. Glia 49:467-479.

Baron W, Decker L, Colognato H, ffrench-Constant C. 2003. Regulation of integrin growth factor interactions in oligodendrocytes by lipid raft microdomains. Curr Biol 13:151-155.

Baron W, Shattil SJ, ffrench-Constant C. 2002. The oligodendrocyte precursor mitogen PDGF stimulates proliferation by activation of alpha(v)beta3 integrins. EMBO J 21:1957-1966.

Bartlett PF, Mackay IR. 1983. The oligodendroglial cell: biology and immunology and relationship to multiple sclerosis. J Clin Lab Immunol 11:1-7.

Baumann N, Pham-Dinh D. 2001. Biology of oligodendrocyte and myelin in the mammalian central nervous system. Physiol Rev 81: 871-927.

Bhat MA. 2003. Molecular organization of the axo-glial junctions. Curr Opin Neurobiol 13:552-559.

Bosio A, Binczek E, Stoffel W. 1996. Functional breakdown of the lipid bilayer of the myelin membrane in central and peripheral nervous system by disrupted galactocerebroside synthesis. Proc Natl Acad Sci U S A 93:13280-13285.

Bosio A, Bussow H, Adam J, Stoffel W. 1998. Galactosphingolipids and axono-glial interaction in myelin of the central nervous system. Cell Tissue Res 292:199-210.

Boyanapalli M, Kottis V, Lahoud O, Bamri-Ezzine S, Braun PE, Mikol DD. (2005). Oligodendrocytemyelin glycoprotein is present in lipid rafts and caveolin-1-enriched membranes. Glia 52:219-227.

Bronstein JM, Tiwari-Woodruff S, Buznikov AG, Stevens DB. 2000. Involvement of OSP/claudin-11 in oligodendrocyte membrane interactions: role in biology and disease. J Neurosci Res 59:706-711.

Brown DA, London E. 1998. Functions of lipid rafts in biological membranes. Annu Rev Cell Dev Biol 14:111-136.

Brown DA, London E. 2000. Structure and function of sphingolipid- and cholesterol-rich membrane rafts. J Biol Chem 275:17221-17224. 
Brown DA, Rose JK. 1992. Sorting of GPI-anchored proteins to glycolipid-enriched membrane subdomains during transport to the apical cell surface. Cell 68:533-544.

Brown MC, Besio Moreno M, Bongarzone ER, Cohen PD, Soto EF, Pasquini JM. 1993. Vesicular transport of myelin proteolipid and cerebroside sulfates to the myelin membrane. J Neurosci Res 35:402-408.

Brown RE. 1998. Sphingolipid organization in biomembranes: what physical studies of model membranes reveal. J Cell Sci 111:1-9.

Brügger B, Graham C, Leibrecht I, Mombelli E, Jen A, Wieland F, Morris R. 2004. The membrane domains occupied by glycosylphosphatidylinositol-anchored prion protein and Thy-1 differ in lipid composition. J Biol Chem 279:7530-7536.

Calver AR, Hall AC, Yu WP, Walsh FS, Heath JK, Betsholtz C, Richardson WD. 1998. Oligodendrocyte population dynamics and the role of PDGF in vivo. Neuron 20:869-882.

Chamberlain LH. 2004. Detergents as tools for the purification and classification of lipid rafts. FEBS Lett 559:1-5.

Charles P, Tait S, Faivre-Sarrailh C, Barbin G, Gunn-Moore F, Denisenko-Nehrbass N, Guennoc AM, Girault JA, Brophy PJ, Lubetzki C. 2002. Neurofascin is a glial receptor for the paranodin/Casprcontactin axonal complex at the axoglial junction. Curr Biol 12:217-220.

Cheong KH, Zacchetti D, Schneeberger EE, Simons K. 1999. VIP17/MAL, a lipid raft-associated protein, is involved in apical transport in MDCK cells. Proc Natl Acad Sci U S A 96:6241-6248.

Colognato H, Baron W, Avellana-Adalid V, Relvas JB, Baron-Van Evercooren A, Georges-Labouesse E, ffrench-Constant C. 2002. CNS integrins switch growth factor signalling to promote targetdependent survival. Nat Cell Biol 4:833-841.

Colognato H, Ramachandrappa S, Olsen IM, ffrench-Constant C. 2004. Integrins direct Src family kinases to regulate distinct phases of oligodendrocyte development. J Cell Biol 167:365-375.

de Almeida RF, Fedorov A, Prieto M. 2003. Sphingomyelin/phosphatidylcholine/cholesterol phase diagram: boundaries and composition of lipid rafts. Biophys J 85:2406-2416.

de Vries H, Hoekstra D. 2000. On the biogenesis of the myelin sheath: cognate polarized trafficking pathways in oligodendrocytes. Glycoconj J 17:181-190.

de Vries H, Schrage C, Hoekstra D. 1998. An apical-type trafficking pathway is present in cultured oligodendrocytes but the sphingolipid-enriched myelin membrane is the target of a basolateral-type pathway. Mol Biol Cell 9:599-609.

Deber CM, Reynolds SJ. 1991. Central nervous system myelin: structure, function, and pathology. Clin Biochem 24:113-134.

DeBruin LS, Haines JD, Wellhauser LA, Radeva G, Schonmann V, Bienzle D, Harauz G. 2005. Developmental partitioning of myelin basic protein into membrane microdomains. J Neurosci Res 80 : 211-225.

Decker L, Baron W, Ffrench-Constant C. 2004. Lipid rafts: microenvironments for integrin-growth factor interactions in neural development. Biochem Soc Trans 32:426-430.

Decker L, ffrench-Constant C. 2004. Lipid rafts and integrin activation regulate oligodendrocyte survival. J Neurosci 24:3816-3825.

Domeniconi M, Cao Z, Spencer T, Sivasankaran R, Wang K, Nikulina E, Kimura N, Cai H, Deng K, Gao Y, He Z, Filbin M. 2002. Myelin-associated glycoprotein interacts with the Nogo66 receptor to 
inhibit neurite outgrowth. Neuron 35:283-290.

Dunn RC. 1999. Near-field scanning optical microscopy. Chem Rev 99:2891-2928.

Edidin M. 1997. Lipid microdomains in cell surface membranes. Curr Opin Struct Biol 7:528-532.

Edidin M. 2001a. Shrinking patches and slippery rafts: scales of domains in the plasma membrane. Trends Cell Biol 11:492-496.

Edidin M. 2001b. Near-field scanning optical microscopy, a siren call to biology. Traffic 2:797-803.

Edidin M. 2003. The State of Lipid Rafts: From Model Membranes to Cells. Annu Rev Biophys Biomol Struct 32:257-283.

ffrench-Constant C, Colognato H. 2004. Integrins: versatile integrators of extracellular signals. Trends Cell Biol 14:678-686.

Foster LJ, De Hoog CL, Mann M. 2003. Unbiased quantitative proteomics of lipid rafts reveals high specificity for signaling factors. Proc Natl Acad Sci U S A 100:5813-5818.

Fournier AE, GrandPre T, Strittmatter SM. 2001. Identification of a receptor mediating Nogo-66 inhibition of axonal regeneration. Nature 409:341-346.

Frank M. 2000. MAL, a proteolipid in glycosphingolipid enriched domains: functional implications in myelin and beyond. Prog Neurobiol 60:531-544.

Frank M, van der Haar ME, Schaeren-Wiemers N, Schwab ME. 1998. rMAL is a glycosphingolipidassociated protein of myelin and apical membranes of epithelial cells in kidney and stomach. J Neurosci 18:4901-4913.

Friedrichson T, Kurzchalia TV. 1998. Microdomains of GPI-anchored proteins in living cells revealed by crosslinking. Nature 394:802-805.

Gaus K, Gratton E, Kable EP, Jones AS, Gelissen I, Kritharides L, Jessup W. (2003). Visualizing lipid structure and raft domains in living cells with two-photon microscopy. Proc Natl Acad Sci U S A 100: 15554-15559.

Gielen E, Vercammen J, Sýkora J, Humpolíčková J, Vandeven M, Benda A, Hellings N, Hof M, Engelborghs Y, Steels P, Ameloot M. 2005. Diffusion of sphingomyelin and myelin oligodendrocyte glycoprotein in the membrane of OLN-93 oligodendroglial cells studied by fluorescence correlation spectroscopy. C R Biol 328:1057-1064.

Gillespie CS, Wilson R, Davidson A, Brophy PJ. 1989. Characterization of a cytoskeletal matrix associated with myelin from rat brain. Biochem J 260:689-696.

Giocondi MC, Milhiet PE, Dosset P, Le Grimellec C. 2004. Use of cyclodextrin for AFM monitoring of model raft formation. Biophys J 86:861-869.

Gow A, Southwood CM, Li JS, Pariali M, Riordan GP, Brodie SE, Danias J, Bronstein JM, Kachar B, Lazzarini RA. 1999. CNS myelin and sertoli cell tight junction strands are absent in Osp/claudin-11 null mice. Cell 99:649-659.

Hardy R, Reynolds R. 1993. Neuron-oligodendroglial interactions during central nervous system development. J Neurosci Res 36:121-126.

Heerklotz H. 2002. Triton promotes domain formation in lipid raft mixtures. Biophys J 83:2693-2701.

Heerklotz H, Szadkowska H, Anderson T, Seelig J. 2003. The sensitivity of lipid domains to small perturbations demonstrated by the effect of Triton. J Mol Biol 329:793-799. 
Helms JB, Zurzolo C. 2004. Lipids as targeting signals: lipid rafts and intracellular trafficking. Traffic $5: 247-254$.

Henderson RM, Edwardson JM, Geisse NA, Saslowsky DE. 2004. Lipid rafts: feeling is believing. News Physiol Sci 19:39-43.

Hoekstra D, Maier O, van der Wouden JM, Slimane TA, van IJzendoorn SC. 2003. Membrane dynamics and cell polarity: the role of sphingolipids. J Lipid Res 44:869-877.

Humpolíčková J, Gielen E, Benda A, Fagulová V, Vercammen J, Hof M, Ameloot M, Engelborghs Y. 2006. Probing diffusion laws within cellular membranes by Z-scan fluorescence correlation spectroscopy. Biophys J Epub ahead of print doi:10.1529/biophysj.106.089474.

Iglesias A, Bauer J, Litzenburger T, Schubart A, Linington C. 2001. T- and B-cell responses to myelin oligodendrocyte glycoprotein in experimental autoimmune encephalomyelitis and multiple sclerosis. Glia 36:220-234.

Ikonen E. 2001. Roles of lipid rafts in membrane transport. Curr.Opin.Cell Biol. 13:470-477.

Ikonen E, Simons K. 1998. Protein and lipid sorting from the trans-Golgi network to the plasma membrane in polarized cells. Semin Cell Dev Biol 9:503-509.

Ipsen JH, Karlstrom G, Mouritsen OG, Wennerstrom H, Zuckermann MJ. 1987. Phase equilibria in the phosphatidylcholine-cholesterol system. Biochim Biophys Acta 905:162-172.

Jain MK, White HB 3rd. 1977. Long-range order in biomembranes. Adv Lipid Res 15:1-60.

Johns TG, Bernard CC. 1999. The structure and function of myelin oligodendrocyte glycoprotein. J Neurochem 72:1-9.

Karnovsky MJ, Kleinfeld AM, Hoover RL, Klausner RD. 1982. The concept of lipid domains in membranes. J Cell Biol 94:1-6.

Kenworthy AK. 2005. Where do we go from here? Meeting Report on the Biophysical Society Discussion on 'Probing Membrane Microdomains', October 28-31, 2004, Asilomar, CA, USA. Traffic 6:518-523.

Kenworthy AK, Edidin M. 1998. Distribution of a glycosylphosphatidylinositol-anchored protein at the apical surface of MDCK cells examined at a resolution of $<100$ A using imaging fluorescence resonance energy transfer. J Cell Biol 142:69-84.

Kenworthy AK, Edidin M. 1999. Imaging fluorescence resonance energy transfer as probe of membrane organization and molecular associations of GPI-anchored proteins. Methods Mol Biol 116: 37-49.

Kenworthy AK, Nichols BJ, Remmert CL, Hendrix GM, Kumar M, Zimmerberg J, LippincottSchwartz J. 2004. Dynamics of putative raft-associated proteins at the cell surface. J Cell Biol 165: 735-746.

Kim T, Fiedler K, Madison DL, Krueger WH, Pfeiffer SE. 1995. Cloning and characterization of MVP17: a developmentally regulated myelin protein in oligodendrocytes . J Neurosci Res 42:413-422.

Kim T, Pfeiffer SE. 1999. Myelin glycosphingolipid/cholesterol-enriched microdomains selectively sequester the non-compact myelin proteins CNP and MOG. J Neurocytol 28:281-293.

Kim T, Pfeiffer SE. 2002. Subcellular localization and detergent solubility of MVP17/rMAL, a lipid raft-associated protein in oligodendrocytes and myelin. J Neurosci Res 69:217-226.

Kiyokawa E, Baba T, Otsuka N, Makino A, Ohno S, Kobayashi T. 2005. Spatial and functional 
heterogeneity of sphingolipid-rich membrane domains. J Biol Chem 280:24072-24084.

Klausner RD, Kleinfeld AM, Hoover RL, Karnovsky MJ. 1980. Lipid domains in membranes. Evidence derived from structural perturbations induced by free fatty acids and lifetime heterogeneity analysis. J Biol Chem 255:1286-1295.

Klein C, Krämer EM, Cardine AM, Schraven B, Brandt R, Trotter J. 2002. Process outgrowth of oligodendrocytes is promoted by interaction of fyn kinase with the cytoskeletal protein tau. J Neurosci 22:698-707.

Kroepfl JF, Gardinier MV. 2001. Mutually exclusive apicobasolateral sorting of two oligodendroglial membrane proteins, proteolipid protein and myelin/oligodendrocyte glycoprotein, in Madin-Darby canine kidney cells. J Neurosci Res 66:1140-1148

Krämer EM, Klein C, Koch T, Boytinck M, Trotter J. 1999. Compartmentation of Fyn kinase with glycosylphosphatidylinositol- anchored molecules in oligodendrocytes facilitates kinase activation during myelination. J Biol Chem 274:29042-29049.

Krämer EM, Koch T, Niehaus A, Trotter J. 1997. Oligodendrocytes direct glycosyl phosphatidylinositol-anchored proteins to the myelin sheath in glycosphingolipid-rich complexes. J Biol Chem 272:8937-8945.

Krämer EM, Schardt A, Nave KA. 2001. Membrane traffic in myelinating oligodendrocytes. Micros Res Tech 52:656-671.

Kusumi A, Ike H, Nakada C, Murase K, Fujiwara T. 2005. Single-molecule tracking of membrane molecules: plasma membrane compartmentalization and dynamic assembly of raft-philic signaling molecules. Semin Immunol 17:3-21.

Kusumi A, Koyama-Honda I, Suzuki K. 2004. Molecular dynamics and interactions for creation of stimulation-induced stabilized rafts from small unstable steady-state rafts. Traffic 5:213-230.

Kusumi A, Suzuki K. 2005. Toward understanding the dynamics of membrane-raft-based molecular interactions. Biochim Biophys Acta 1746:234-251.

Lagerholm BC, Weinreb GE, Jacobson K, Thompson NL. 2005. Detecting microdomains in intact cell membranes. Annu Rev Phys Chem 56:309-336.

Lai EC. 2003. Lipid rafts make for slippery platforms. J Cell Biol 162:365-370.

Lee AG. 2001. Myelin: Delivery by raft. Curr Biol 11:R60-R62.

Lee J, Gravel M, Zhang R, Thibault P, Braun PE. 2005. J Cell Biol 170:661-673.

Lentz BR, Barrow DA, Hoechli M. 1980. Cholesterol-phosphatidylcholine interactions in multilamellar vesicles. Biochem 19:1943-1954.

Linington C, Bradl M, Lassmann H, Brunner C, Vass K. 1988. Augmentation of demyelination in rat acute allergic encephalomyelitis by circulating mouse monoclonal antibodies directed against a myelin/oligodendrocyte glycoprotein. Am J Pathol 130:443-454.

Linington C, Lassmann H. 1987. Antibody responses in chronic relapsing experimental allergic encephalomyelitis: correlation of serum demyelinating activity with antibody titre to the myelin/oligodendrocyte glycoprotein (MOG). J Neuroimmunol 17:61-69.

Lippincott-Schwartz J, Altan-Bonnet N, Patterson GH. 2003. Photobleaching and photoactivation: following protein dynamics in living cells. Nat Cell Biol Suppl:S7-14.

Liu BP, Fournier A, GrandPre T, Strittmatter SM. 2002. Myelin-associated glycoprotein as a functional 
ligand for the Nogo-66 receptor. Science 297:1190-1193.

Lommerse PH, Spaink HP, Schmidt T. 2004. In vivo plasma membrane organization: results of biophysical approaches. Biochim Biophys Acta 1664:119-131.

London E. 2002. Insights into lipid raft structure and formation from experiments in model membranes. Curr Opin Struct Biol 12:480-486.

London E, Brown DA. 2000. Insolubility of lipids in triton X-100: physical origin and relationship to sphingolipid/cholesterol membrane domains (rafts). Biochim Biophys Acta 1508:182-195.

Madore N, Smith KL, Graham CH, Jen A, Brady K, Hall S, Morris R. 1999. Functionally different GPI proteins are organized in different domains on the neuronal surface. EMBO J 18:6917-6926.

Maier O, van der Heide T, van Dam AM, Baron W, de Vries H, Hoekstra D. 2005. Alteration of the extracellular matrix interferes with raft association of neurofascin in oligodendrocytes. Potential significance for multiple sclerosis? Mol Cell Neurosci 28:390-401.

Marta C, Taylor CM, Cheng S, Quarles RH, Bansal R, Pfeiffer S. 2004. Myelin associated glycoprotein cross-linking triggers its partitioning into lipid rafts, specific signaling events and cytoskeletal rearrangements in oligodendrocytes. Neuron Glia Biology 1:35-46.

Marta CB, Montano MB, Taylor CM, Taylor AL, Bansal R, Pfeiffer SE. 2005. Signaling cascades activated upon antibody cross-linking of myelin oligodendrocyte glycoprotein: potential implications for multiple sclerosis. J Biol Chem 280:8985-8993.

Marta CB, Taylor CM, Coetzee T, Kim T, Winkler S, Bansal R, Pfeiffer SE. 2003. Antibody crosslinking of myelin oligodendrocyte glycoprotein leads to its rapid repartitioning into detergent-insoluble fractions, and altered protein phosphorylation and cell morphology. J Neurosci 23:5461-5471.

Martin-Belmonte F, Puertollano R, Millan J, Alonso MA. 2000. The MAL proteolipid is necessary for the overall apical delivery of membrane proteins in the polarized epithelial Madin-Darby canine kidney and fischer rat thyroid cell lines. Mol Biol Cell 11:2033-2045.

Menon K, Rasband MN, Taylor CM, Brophy P, Bansal R, Pfeiffer SE. 2003. The myelin-axolemmal complex: biochemical dissection and the role of galactosphingolipids. J Neurochem 87:995-1009.

Morita K, Sasaki H, Fujimoto K, Furuse M, Tsukita S. 1999. Claudin-11/OSP-based tight junctions of myelin sheaths in brain and Sertoli cells in testis. J Cell Biol 145:579-588.

Mukherjee S, Maxfield FR. 2004. Membrane domains. Annu Rev Cell Dev Biol 20:839-866.

Mátko J, Szöllősi J. 2002. Landing of immune receptors and signal proteins on lipid rafts: a safe way to be spatio-temporally coordinated? Immunol Lett 82:3-15.

Osterhout DJ, Wolven A, Wolf RM, Resh MD, Chao MV. 1999. Morphological differentiation of oligodendrocytes requires activation of Fyn tyrosine kinase. J Cell Biol 145:1209-1218.

Paladino S, Sarnataro D, Pillich R, Tivodar S, Nitsch L, Zurzolo C. 2004. Protein oligomerization modulates raft partitioning and apical sorting of GPI-anchored proteins. J Cell Biol 167:699-709.

Pasquini JM, Guarna MM, Besio-Moreno MA, Iturregui MT, Oteiza PI, Soto EF. 1989. Inhibition of the synthesis of glycosphingolipids affects the translocation of proteolipid protein to the myelin membrane. J Neurosci Res 22:289-296.

Pereyra PM, Horvath E, Braun PE. 1988. Triton X-100 extractions of central nervous system myelin indicate a possible role for the minor myelin proteins in the stability in lamellae. Neurochem Res 13:583-595. 
Pfeiffer SE, Warrington AE, Bansal R. 1993. The oligodendrocyte and its many cellular processes. Trends Cell Biol 3:191-197.

Phair RD, Misteli T. 2001. Kinetic modelling approaches to in vivo imaging. Nat Rev Mol Cell Biol 2: 898-907.

Pike LJ. 2004. Lipid rafts: heterogeneity on the high seas. Biochem J 378:281-292.

Pike LJ, Han X, Gross RW. 2005. Epidermal growth factor receptors are localized to lipid rafts that contain a balance of inner and outer leaflet lipids: a shotgun lipidomics study. J Biol Chem 280:2679626804 .

Pralle A, Keller P, Florin EL, Simons K, Horber JK. 2000. Sphingolipid-cholesterol rafts diffuse as small entities in the plasma membrane of mammalian cells. J Cell Biol 148:997-1008.

Prior IA, Muncke C, Parton RG, Hancock JF. 2003. Direct visualization of Ras proteins in spatially distinct cell surface microdomains. J Cell Biol 160:165-170.

Puertollano R, Martin-Belmonte F, Millan J, de Marco MC, Albar JP, Kremer L, Alonso MA. 1999. The MAL proteolipid is necessary for normal apical transport and accurate sorting of the influenza virus hemagglutinin in Madin-Darby canine kidney cells. J Cell Biol 145:141-151.

Rao M, Mayor S. 2005. Use of Forster's resonance energy transfer microscopy to study lipid rafts. Biochim Biophys Acta 1746:221-233.

Reindl M, Linington C, Brehm U, Egg R, Dilitz E, Deisenhammer F, Poewe W, Berger T. 1999. Antibodies against the myelin oligodendrocyte glycoprotein and the myelin basic protein in multiple sclerosis and other neurological diseases: a comparative study. Brain 122:2047-2056.

Relvas JB, Setzu A, Baron W, Buttery PC, LaFlamme SE, Franklin RJ, ffrench-Constant C. 2001. Expression of dominant-negative and chimeric subunits reveals an essential role for betal integrin during myelination. Curr Biol 11:1039-1043.

Rinia HA, Snel MM, van der Eerden JP, de Kruijff B. 2001. Visualizing detergent resistant domains in model membranes with atomic force microscopy. FEBS Lett 501:92-96.

Ritchie K, Kusumi A. 2004. Role of the membrane skeleton in creation of microdomains. Subcell Biochem 37:233-245.

Saravanan K, Schaeren-Wiemers N, Klein D, Sandhoff R, Schwarz A, Yaghootfam A, Gieselmann V, Franken S. 2004. Specific downregulation and mistargeting of the lipid raft-associated protein MAL in a glycolipid storage disorder. Neurobiol Dis 16:396-406.

Schaeren-Wiemers N, Bonnet A, Erb M, Erne B, Bartsch U, Kern F, Mantei N, Sherman D, Suter U. 2004. The raft-associated protein MAL is required for maintenance of proper axon-glia interactions in the central nervous system. J Cell Biol 166:731-742.

Schaeren-Wiemers N, Valenzuela DM, Frank M, Schwab ME. 1995. Characterization of a rat gene, rMAL, encoding a protein with four hydrophobic domains in central and peripheral myelin. J Neurosci 15:5753-5764.

Schafer DP, Bansal R, Hedstrom KL, Pfeiffer SE, Rasband MN. 2004. Does paranode formation and maintenance require partitioning of neurofascin 155 into lipid rafts? J Neurosci 24:3176-3185.

Schroeder R, London E, Brown D. 1994. Interactions between saturated acyl chains confer detergent resistance on lipids and glycosylphosphatidylinositol (GPI)-anchored proteins: GPI-anchored proteins in liposomes and cells show similar behavior. Proc Natl Acad Sci U S A 91:12130-12134.

Schuck S, Honsho M, Ekroos K, Shevchenko A, Simons K. 2003. Resistance of cell membranes to 
different detergents. Proc Natl Acad Sci U S A 100:5795-5800.

Schuck S, Simons K. 2004. Polarized sorting in epithelial cells: raft clustering and the biogenesis of the apical membrane. J Cell Sci 117:5955-5964.

Sherman DL, Brophy PJ. 2005. Mechanisms of axon ensheathment and myelin growth. Nat Rev Neurosci 6:683-690.

Simons K, Ikonen E. 1997. Functional rafts in cell membranes. Nature 387:569-572.

Simons K, Toomre D. 2000. Lipid rafts and signal transduction. Nat Rev Mol Cell Biol 1:31-39.

Simons K, van Meer G. 1988. Lipid sorting in epithelial cells. Biochemistry 27:6197-6202.

Simons K, Vaz WL. 2004. Model systems, lipid rafts, and cell membranes. Annu Rev Biophys Biomol Struct 33:269-295.

Simons K, Wandinger-Ness A. 1990. Polarized sorting in epithelia. Cell 62:207-210.

Simons M, Krämer EM, Thiele C, Stoffel W, Trotter J. 2000. Assembly of myelin by association of proteolipid protein with cholesterol- and galactosylceramide-rich membrane domains. J.Cell Biol. 151: 143-154.

Skwarek M. 2004. Recent controversy surrounding lipid rafts. Arch Immunol Ther Exp (Warsz) 52: 427-431.

Slimane TA, Trugnan G, Van IJzendoorn SC, Hoekstra D. 2003. Raft-mediated trafficking of apical resident proteins occurs in both direct and transcytotic pathways in polarized hepatic cells: role of distinct lipid microdomains. Mol Biol Cell 14:611-624.

Sperber BR, McMorris FA. 2001. Fyn tyrosine kinase regulates oligodendroglial cell development but is not required for morphological differentiation of oligodendrocytes. J Neurosci Res 63:303-312.

Staneva G, Seigneuret M, Koumanov K, Trugnan G, Angelova MI. 2005. Detergents induce raft-like domains budding and fission from giant unilamellar heterogeneous vesicles: a direct microscopy observation. Chem Phys Lipids 136:55-66.

Tait S, Gunn-Moore F, Collinson JM, Huang J, Lubetzki C. 2000. An oligodendrocyte cell adhesion molecule at the site of assembly of the paranodal axo-glial junction. J.Cell Biol. 150:657-666.

Taylor CM, Coetzee T, Pfeiffer SE. 2002. Detergent-insoluble glycosphingolipid/cholesterol microdomains of the myelin membrane. J Neurochem 81:993-1004.

Umemori H, Sato S, Yagi T, Aizawa S, Yamamoto T. 1994. Initial events of myelination involve Fyn tyrosine kinase signalling. Nature 367:572-576.

van der Haar ME, Visser HW, de Vries H, Hoekstra D. 1998. Transport of proteolipid protein to the plasma membrane does not depend on glycosphingolipid cotransport in oligodendrocyte cultures. J Neurosci Res 51:371-381.

Varma R, Mayor S. 1998. GPI-anchored proteins are organized in submicron domains at the cell surface. Nature 394:798-801.

Vereb G, Szöllősi J, Mátko J, Nagy P, Farkas T, Vigh L, Matyus L, Waldmann TA, Damjanovich S. 2003. Dynamic, yet structured: The cell membrane three decades after the Singer-Nicolson model. Proc Natl Acad Sci U S A 100:8053-8058.

Vinson M, Rausch O, Maycox PR, Prinjha RK, Chapman D, Morrow R, Harper AJ, Dingwall C, Walsh FS, Burbidge SA, Riddell DR. 2003. Lipid rafts mediate the interaction between myelin-associated 
glycoprotein (MAG) on myelin and MAG-receptors on neurons. Mol Cell Neurosci 22:344-352.

Vinson M, Strijbos PJ, Rowles A, Facci L, Moore SE, Simmons DL, Walsh FS. 2001. Myelinassociated glycoprotein interacts with ganglioside GT1b. A mechanism for neurite outgrowth inhibition. J Biol Chem 276:20280-20285.

Vyas AA, Patel HV, Fromholt SE, Heffer-Lauc M, Vyas KA, Dang J, Schachner M, Schnaar RL. 2002. Gangliosides are functional nerve cell ligands for myelin-associated glycoprotein (MAG), an inhibitor of nerve regeneration. Proc Natl Acad Sci U S A 99:8412-8417.

Vyas AA, Schnaar RL. 2001. Brain gangliosides: functional ligands for myelin stability and the control of nerve regeneration. Biochimie 83:677-682.

Wawrezinieck L, Rigneault H, Marguet D, Lenne PF. 2005. Fluorescence correlation spectroscopy diffusion laws to probe the submicron cell membrane organization. Biophys J 89:4029-4042.

Weiss MD, Hammer J, Quarles RH. 2000. Oligodendrocytes in aging mice lacking myelin-associated glycoprotein are dystrophic but not apoptotic. J Neurosci Res 62:772-780.

Wilson BS, Pfeiffer JR, Oliver JM. 2000. Observing FcepsilonRI signaling from the inside of the mast cell membrane. J Cell Biol 149:1131-1142.

Wilson R, Brophy PJ. 1989. Role for the oligodendrocyte cytoskeleton in myelination. J Neurosci Res 22:439-448.

Wingerchuk DM, Lucchinetti CF, Noseworthy JH. 2001. Multiple sclerosis: current pathophysiological concepts. Lab Invest 81:263-281.

Yuan C, Furlong J, Burgos P, Johnston LJ. 2002. The size of lipid rafts: an atomic force microscopy study of ganglioside GM1 domains in sphingomyelin/DOPC/cholesterol membranes. Biophys J 82: 2526-2535.

Zacchetti D, Peranen J, Murata M, Fiedler K, Simons K. 1995. VIP17/MAL, a proteolipid in apical transport vesicles. FEBS Lett 377:465-469.

Zurzolo C, van Meer G, Mayor S. 2003. The order of rafts. Conference on microdomains, lipid rafts and caveolae. EMBO Rep 4:1117-1121.

Zurzolo C, van't Hof W, van Meer G, Rodriguez-Boulan E. 1994. VIP21/caveolin, glycosphingolipid clusters and the sorting of glycosylphosphatidylinositol-anchored proteins in epithelial cells. EMBO J 13:42-53. 
Table 1 Lipid and protein composition of human central nervous system myelin ${ }^{3}$

$\%$ Total dry weight

$\begin{array}{lr}\text { Lipid } & 70.0 \\ \text { Protein } & 30.0\end{array}$

$\begin{array}{ll}\text { Protein } & 30.0\end{array}$

Protein

Myelin basic protein

Proteolipid proteins

Other LH-20 components ${ }^{1}$

Myelin-associated glycoprotein

2',3'-cyclic nucleotide 3'-phosphodiesterase

Others (Wolfgram, glycoproteins, etc.)
$\%$ Total dry weight

30.0

17.5

$<1.0$

4.0

25.0

Lipid

$\%$ Total dry weight

Cholesterol

Galactosylceramide

Sulfatide

Ethanolamine phosphatides

Phosphatidylcholine

Phosphatidylserine

Phosphatidylinositol

Sphingomyelin

Plasmalogens $^{2}$

Gangliosides (primarily GM1 and GM4)

${ }^{1}$ The proteolipid fraction is a family of proteins that can be isolated on Sephadex LH-20 in acidified chloroform-methanol. The major homogeneous protein is PLP

${ }^{2}$ Plasmalogens are ether-linked lipids composed primarily of ethanolamine phosphatides

${ }^{3}$ Adapted from Deber and Reynolds (1991) 
Table 2 Function of myelin-specific proteins

\begin{tabular}{|c|c|}
\hline Myelin component & Function \\
\hline PLP/DM20 & Myelin compaction $^{1}$ \\
\hline MBP & Myelin compaction $^{1}$ \\
\hline MAL & $\begin{array}{l}\text { Might function to form and maintain stable protein-lipid } \\
\text { microdomains in myelin effecting reorganization of myelin } \\
\text { proteins in compact myelin and sorting and transport during } \\
\text { maintenance of the myelin sheath } \\
\text { Maintenance of proper axon-glia interactions }{ }^{2}\end{array}$ \\
\hline MAG & $\begin{array}{l}\text { Myelin stabilization/maintenance of myelin integrity }{ }^{4} \\
\text { Inhibition of neurite outgrowth, i.e. axon regeneration in the } \\
\text { CNS after lesion }\end{array}$ \\
\hline OSP/claudin-11 & $\begin{array}{l}\text { Mediator of parallel-array tight junction strands in CNS } \\
\text { myelin }^{5} \\
\text { May act as a diffusion barrier between compact and non- } \\
\text { compact myelin }\end{array}$ \\
\hline MOG & $\begin{array}{l}\text { May function in transmitting extracellular information to the } \\
\text { interior of oligodendrocytes } \\
\text { Target antigen in the process of demyelination in EAE and } \\
\mathrm{MS}^{8}\end{array}$ \\
\hline CNP & $\begin{array}{l}\text { Microtubule assembly myelin protein }{ }^{9} \\
\text { Process outgrowth }^{9}\end{array}$ \\
\hline NF155 & $\begin{array}{l}\text { Establishment of the paranodal septate junction required for } \\
\text { tight interaction between myelin and axon }{ }^{10}\end{array}$ \\
\hline MOBP & Myelin compaction ${ }^{1}$ \\
\hline
\end{tabular}


Table 3 Overview of extraction conditions in which myelin proteins resist solubilization

\begin{tabular}{|c|c|c|c|c|c|c|c|}
\hline \multirow{2}{*}{ Protein } & \multirow{2}{*}{$\begin{array}{l}\text { Cell/tissue } \\
\text { source }\end{array}$} & \multirow{2}{*}{ Species } & \multirow{2}{*}{ Detergent } & \multicolumn{3}{|c|}{ Extraction condition } & \multirow{2}{*}{ Reference } \\
\hline & & & & Conc & $\begin{array}{c}\text { Incubation } \\
\text { time }\end{array}$ & Temp & \\
\hline \multirow{7}{*}{ PLP/DM20 } & \multirow{6}{*}{ Purified myelin } & \multirow{2}{*}{ 35-days-old mice } & CHAPS & $1 \%$ & $30 \mathrm{~min}$ & $4^{\circ} \mathrm{C} / 37^{\circ} \mathrm{C}$ & \multirow{2}{*}{ Taylor et al. 2002} \\
\hline & & & TX-102 & $1 \%$ & $30 \mathrm{~min}$ & $4^{\circ} \mathrm{C}$ & \\
\hline & & $\begin{array}{l}\text { 4-months-old mice: } \\
\text { WT and MAL KO }\end{array}$ & CHAPS & na & $30 \min$ & $4^{\circ} \mathrm{C}$ & Schaeren-Wiemers et al. 2004 \\
\hline & & Adult mouse brain & CHAPS & $20 \mathrm{mM}$ & $30 \mathrm{~min}$ & $4^{\circ} \mathrm{C}$ & Simons et al. 2000 \\
\hline & & 2-year-old mice & TX-100 & $2 \%$ & $30 \min$ & $4^{\circ} \mathrm{C}$ & Saravanan et al. 2004 \\
\hline & & Bovine brain E20 - E40 & CHAPS & $1.5 \%$ & $30 \mathrm{~min}$ & $4^{\circ} \mathrm{C}$ & Debruin et al. 2005 \\
\hline & Primary OLGs & Mouse OLG 5 DIV & CHAPS & $20 \mathrm{mM}$ & $30 \mathrm{~min}$ & $4^{\circ} \mathrm{C}$ & Simons et al. 2000 \\
\hline \multirow{9}{*}{ MBP } & & & & & & & \\
\hline & \multirow{3}{*}{ Whole brain } & \multirow{2}{*}{ Adult rat } & TX-100 & $1 \%$ & na & $4^{\circ} \mathrm{C}$ & \multirow{2}{*}{ Boyanapalli et al. 2005} \\
\hline & & & CHAPS & $30 \mathrm{mM}$ & na & $4^{\circ} \mathrm{C}$ & \\
\hline & & Rabbit & TX-100 & $1 \%$ & $16 h+24 h$ & $4^{\circ} \mathrm{C}$ & Pereyra et al. 1988 \\
\hline & \multirow{4}{*}{ Purified myelin } & 4 to 6-weeks-old rat & TX-100 & $0.5 \%$ & $3 \min$ & RT & Gillespie et al. 1989 \\
\hline & & 35-days-old mice & TX-102 & $1 \%$ & $30 \mathrm{~min}$ & $4^{\circ} \mathrm{C}$ & Taylor et al. 2002 \\
\hline & & $\begin{array}{l}\text { 4-months-old mice: } \\
\text { WT and MAL KO }\end{array}$ & CHAPS & na & $30 \mathrm{~min}$ & $4^{\circ} \mathrm{C}$ & Schaeren-Wiemers et al. 2004 \\
\hline & & Bovine brain E29 - E40 & CHAPS & $1.5 \%$ & $30 \mathrm{~min}$ & $4^{\circ} \mathrm{C}$ & Debruin et al. 2005 \\
\hline & Primary OLGs & $\begin{array}{c}1 \text { to } 2 \text {-days-old rat brain } \\
\text { OLGs } 12 \text { DIV }\end{array}$ & TX-100 & $0.5 \%$ & $3 \mathrm{~min}$ & RT & Wilson and Brophy 1989 \\
\hline \multirow{5}{*}{ MAL } & \multirow{3}{*}{ Purified myelin } & 30-days-old rat brain & TX-100 & $1 \%$ & $30 \min$ & $4^{\circ} \mathrm{C}$ & Kim and Pfeiffer 2002 \\
\hline & & Adult rat brain & CHAPS & $20 \mathrm{mM}$ & $2 \mathrm{~h}$ & $4^{\circ} \mathrm{C}$ & Kim et al. 1995 \\
\hline & & 2-year-old mice & TX-100 & $2 \%$ & $30 \mathrm{~min}$ & $4^{\circ} \mathrm{C}$ & Saravanan et al. 2004 \\
\hline & Primary OLGs & Mature rat OLGs & CHAPS & $40 \mathrm{mM}$ & $30 \mathrm{~min}$ & $4^{\circ} \mathrm{C}$ & Kim et al. 1995 \\
\hline & Spinal cord & 14-days-old Rat & CHAPS & $1 \%$ & $30 \mathrm{~min}$ & $4^{\circ} \mathrm{C}$ & Frank et al. 1998 \\
\hline \multirow{5}{*}{ MAG } & Whole brain & Mouse & Lubrol WX & $1 \%$ & na & $4^{\circ} \mathrm{C}$ & Vinson et al. 2003 \\
\hline & \multirow{3}{*}{ Purified myelin } & Adult mouse brain & CHAPS & $20 \mathrm{mM}$ & $30 \mathrm{~min}$ & $4^{\circ} \mathrm{C}$ & Simons et al. 2000 \\
\hline & & 35-days-old mice & CHAPS/Brij 96V & $1 \%$ & $30 \mathrm{~min}$ & $4^{\circ} \mathrm{C} / 37^{\circ} \mathrm{C}$ & Taylor et al. 2002 \\
\hline & & Bovine brain E29 - E40 & CHAPS & $1.5 \%$ & $30 \min$ & $4^{\circ} \mathrm{C}$ & Debruin et al. 2005 \\
\hline & Primary OLGs & $\begin{array}{c}1 \text { to } 2 \text {-days-old rat brain } \\
\text { OLGs } 6 \text { DIV }\end{array}$ & Lubrol WX & $1 \%$ & na & $4^{\circ} \mathrm{C}$ & Vinson et al. 2003 \\
\hline
\end{tabular}




\begin{tabular}{|c|c|c|c|c|c|c|c|}
\hline & Spinal cord & Rat (WT or EAE) & Lubrol WX & $0.5 \%$ & $30 \mathrm{~min}$ & $4^{\circ} \mathrm{C}$ & Maier et al. 2005 \\
\hline Cx-32 & Purified myelin & 30-days-old rat brain & TX-100 & $1 \%$ & $30 \mathrm{~min}$ & $4^{\circ} \mathrm{C} / 37^{\circ} \mathrm{C}$ & Kim and Pfeiffer 1999 \\
\hline \multirow[b]{2}{*}{ OSP } & \multirow[b]{2}{*}{ Purified myelin } & 30-days-old rat brain & TX-100 & $1 \%$ & $30 \mathrm{~min}$ & $4^{\circ} \mathrm{C}$ & Kim and Pfeiffer 1999 \\
\hline & & 35-days-old mice & $\begin{array}{c}\text { TX-100 / CHAPS } \\
\text { Brij 96V / TX-102 } \\
\end{array}$ & $1 \%$ & $30 \mathrm{~min}$ & $4^{\circ} \mathrm{C}$ & Taylor et al. 2002 \\
\hline \multirow{7}{*}{ MOG } & \multirow{6}{*}{ Purified myelin } & 30-davs-old rat brain & TX-100 & $1 \%$ & $30 \mathrm{~min}$ & $4^{\circ} \mathrm{C}$ & Kim and Pfeiffer 1999 \\
\hline & & 35-days-old mice & $\begin{array}{c}\text { TX-100/CHAPS } \\
\text { Brij 96V/TX-102 }\end{array}$ & $1 \%$ & $30 \mathrm{~min}$ & $4^{\circ} \mathrm{C}$ & Taylor et al. 2002 \\
\hline & & $\begin{array}{l}\text { 4-months-old mice: } \\
\text { WT and MAL KO }\end{array}$ & CHAPS & na & $30 \mathrm{~min}$ & $4^{\circ} \mathrm{C}$ & Schaeren-Wiemers et al. 2004 \\
\hline & & Adult mouse brain & CHAPS & $20 \mathrm{mM}$ & $30 \mathrm{~min}$ & $4^{\circ} \mathrm{C}$ & Simons et al. 2000 \\
\hline & & 2-year-old mice & TX-100 & $2 \%$ & $30 \mathrm{~min}$ & $4^{\circ} \mathrm{C}$ & Saravanan et al. 2004 \\
\hline & & Bovine brain E20 - E40 & CHAPS & $1.5 \%$ & $30 \mathrm{~min}$ & $4^{\circ} \mathrm{C}$ & Debruin et al. 2005 \\
\hline & Primary OLGs & Mouse OLG 5 DIV & CHAPS & $20 \mathrm{mM}$ & $30 \mathrm{~min}$ & $4^{\circ} \mathrm{C}$ & Simons et al. 2000 \\
\hline & & & & & & & \\
\hline \multirow{10}{*}{ CNP } & \multirow{8}{*}{ Purified myelin } & 30-days-old rat & TX-100 & $1 \%$ & $30 \mathrm{~min}$ & $4^{\circ} \mathrm{C}$ & Kim and Pfeiffer 1999 \\
\hline & & 4-6 weeks old rat & TX-100 & $0.5 \%$ & $3 \min$ & RT & Gillespie et al. 1989 \\
\hline & & 35-days-old mice & $\begin{array}{l}\text { TX-100 / CHAPS / } \\
\text { Brij 96V / TX-102 }\end{array}$ & $1 \%$ & $30 \mathrm{~min}$ & $4^{\circ} \mathrm{C} / 37^{\circ} \mathrm{C}$ & Taylor et al. 2002 \\
\hline & & 2-year-old mice & TX-100 & $2 \%$ & $30 \mathrm{~min}$ & $4^{\circ} \mathrm{C}$ & Saravanan et al. 2004 \\
\hline & & \multirow{2}{*}{ Mouse } & TX-100 & $1 \%$ & na & $4^{\circ} \mathrm{C}$ & \multirow{2}{*}{ Boyanapalli et al. 2005} \\
\hline & & & CHAPS & $30 \mathrm{mM}$ & na & $4^{\circ} \mathrm{C}$ & \\
\hline & & Rabbit & TX-100 & $1 \%$ & $16 h+24 h$ & $4^{\circ} \mathrm{C}$ & Pereyra et al. 1988 \\
\hline & & Bovine brain E11 - E40 & CHAPS & $1.5 \%$ & $30 \mathrm{~min}$ & $4^{\circ} \mathrm{C}$ & Debruin et al. 2005 \\
\hline & Primary OLGs & $\begin{array}{l}\text { 1-2 day old rat brain } \\
\text { OLGs } 12 \text { DIV }\end{array}$ & TX-100 & $0.5 \%$ & $3 \mathrm{~min}$ & RT & Wilson and Brophy 1989 \\
\hline & Optic nerve & $\begin{array}{l}\mathrm{p} 13, \mathrm{p} 18, \mathrm{p} 24 \text { and } \\
2 \text { months old rat }\end{array}$ & TX-100 & $1 \%$ & $1 \mathrm{~h}$ & $4^{\circ} \mathrm{C}$ & Schafer et al. 2004 \\
\hline & & & & & & & \\
\hline \multirow{4}{*}{ OMgp } & \multirow{2}{*}{ Whole brain } & \multirow{2}{*}{ Adult rat } & TX100 & $1 \%$ & na & $4^{\circ} \mathrm{C}$ & \multirow{4}{*}{ Boyanapalli et al. 2005} \\
\hline & & & CHAPS & $30 \mathrm{mM}$ & na & $4^{\circ} \mathrm{C}$ & \\
\hline & \multirow{2}{*}{ Purified myelin } & \multirow{2}{*}{ Mouse } & TX100 & $1 \%$ & na & $4^{\circ} \mathrm{C}$ & \\
\hline & & & CHAPS & $30 \mathrm{mM}$ & na & $4^{\circ} \mathrm{C}$ & \\
\hline NF155 & Purified myelin & 4-months-old mice & CHAPS & na & $30 \mathrm{~min}$ & $4^{\circ} \mathrm{C}$ & Schaeren-Wiemers et al. 2004 \\
\hline
\end{tabular}




\begin{tabular}{|c|c|c|c|c|c|c|c|}
\hline & \multirow{3}{*}{ Primary OLGs } & \multirow{2}{*}{ Rat OLGs 6 DIV } & TX-100 & $1 \%$ & $30 \mathrm{~min}$ & $4^{\circ} \mathrm{C}$ & \multirow{2}{*}{ Maier et al. 2005} \\
\hline & & & Lubrol WX & $0.5 \%$ & $30 \mathrm{~min}$ & $4^{\circ} \mathrm{C}$ & \\
\hline & & premyelinating mouse OLGs & TX-100 & $1 \%$ & $1 \mathrm{~h}$ & $4^{\circ} \mathrm{C}$ & Schafer et al. 2004 \\
\hline & \multirow{2}{*}{ Spinal cord } & \multirow{2}{*}{ Rat (WT or EAE) } & TX-100 & $1 \%$ & $30 \mathrm{~min}$ & $4^{\circ} \mathrm{C}$ & \multirow{2}{*}{ Maier et al. 2005} \\
\hline & & & Lubrol WX & $0.5 \%$ & $30 \mathrm{~min}$ & $4^{\circ} \mathrm{C}$ & \\
\hline & Optic nerve & $\begin{array}{c}\mathrm{p} 13, \mathrm{p} 18, \mathrm{p} 24 \text { and } \\
2 \text { months old rat }\end{array}$ & TX-100 & $1 \%$ & $1 \mathrm{~h}$ & $4^{\circ} \mathrm{C}$ & Schafer et al. 2004 \\
\hline & & & & & & & \\
\hline \multirow{6}{*}{ NCAM 120} & \multirow{3}{*}{ Purified myelin } & 35-days-old mice & $\begin{array}{l}\text { TX-100 / CHAPS / } \\
\text { Brij 96V / TX-102 }\end{array}$ & $1 \%$ & $30 \mathrm{~min}$ & $4^{\circ} \mathrm{C}$ & Taylor et al. 2002 \\
\hline & & Adult mouse brain & TX-100 & $2 \%$ & $30 \mathrm{~min}$ & $4^{\circ} \mathrm{C}$ & Krämer et al. 1997, 1999 \\
\hline & & 2-year-old mice & TX-100 & $2 \%$ & $30 \mathrm{~min}$ & $4^{\circ} \mathrm{C}$ & Saravanan et al. 2004 \\
\hline & \multirow{2}{*}{ Primary OLGs } & Mouse OLGs 5/8 DIV & TX-100 & $2 \%$ & $30 \mathrm{~min}$ & $4^{\circ} \mathrm{C}$ & Krämer et al. 1997, 1999 \\
\hline & & Mouse OLG 5 DIV & CHAPS & $20 \mathrm{mM}$ & $30 \mathrm{~min}$ & $4^{\circ} \mathrm{C}$ & Simons et al. 2000 \\
\hline & Cell line & Oli-neu (mouse) & TX-100 & $2 \%$ & $30 \mathrm{~min}$ & $4^{\circ} \mathrm{C}$ & Krämer et al. 1997 \\
\hline \multirow{4}{*}{ F3/contactin } & \multirow{2}{*}{ Purified myelin } & 4-months-old mice & CHAPS & na & $30 \mathrm{~min}$ & $4^{\circ} \mathrm{C}$ & Schaeren-Wiemers et al. 2004 \\
\hline & & Adult mouse brain & TX-100 & $2 \%$ & $30 \mathrm{~min}$ & $4^{\circ} \mathrm{C}$ & Krämer et al. 1997, 1999 \\
\hline & \multirow{2}{*}{ Primary OLGs } & Mouse OLGs 5/8 DIV & TX-100 & $2 \%$ & $30 \mathrm{~min}$ & $4^{\circ} \mathrm{C}$ & Krämer et al. 1997, 1999 \\
\hline & & Mouse OLG 5 DIV & CHAPS & $20 \mathrm{mM}$ & $30 \mathrm{~min}$ & $4^{\circ} \mathrm{C}$ & Simons et al. 2000 \\
\hline
\end{tabular}


Myelinating mature

oligodendrocyte in vitro

producing myelin sheets

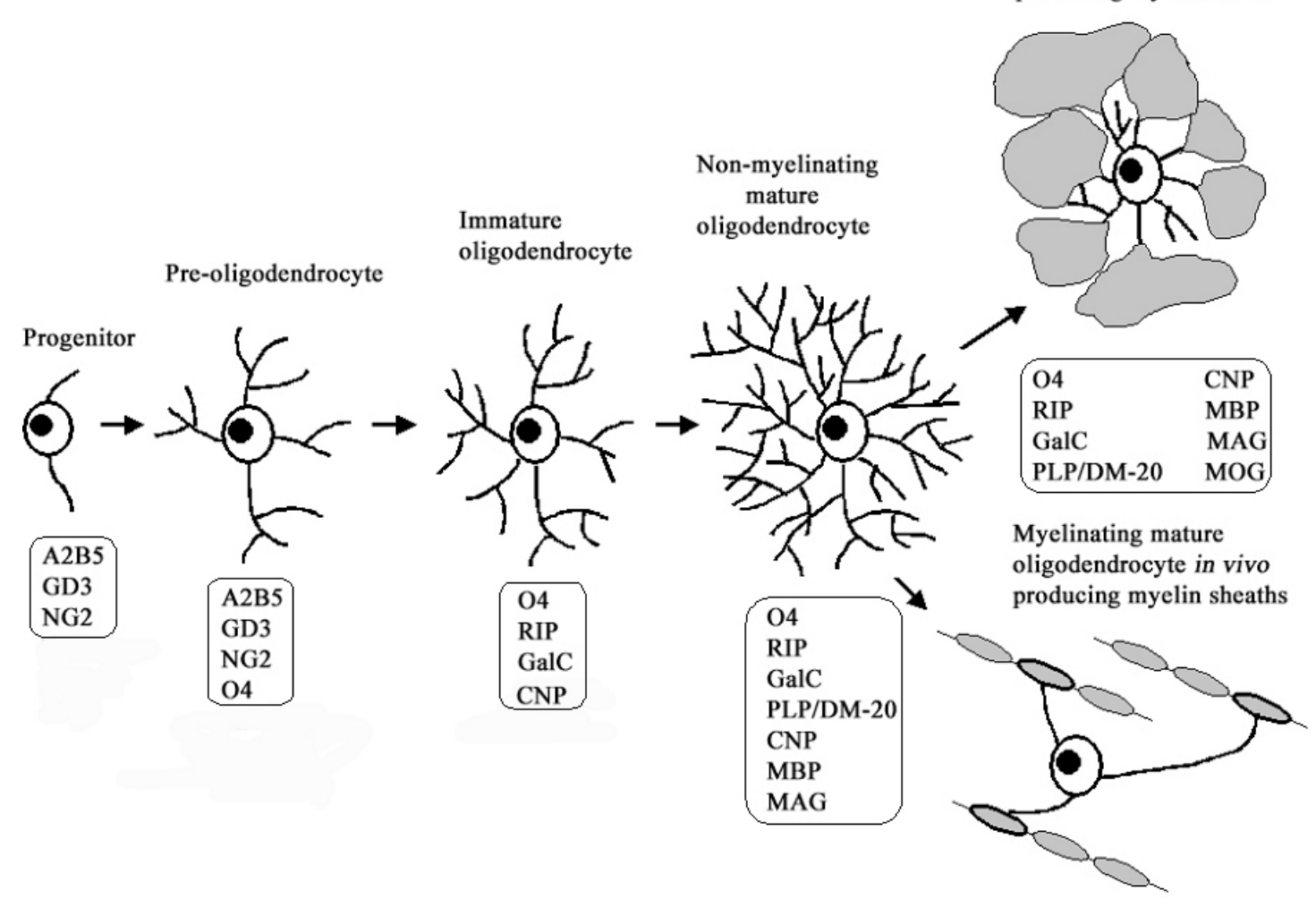

Figure 1 


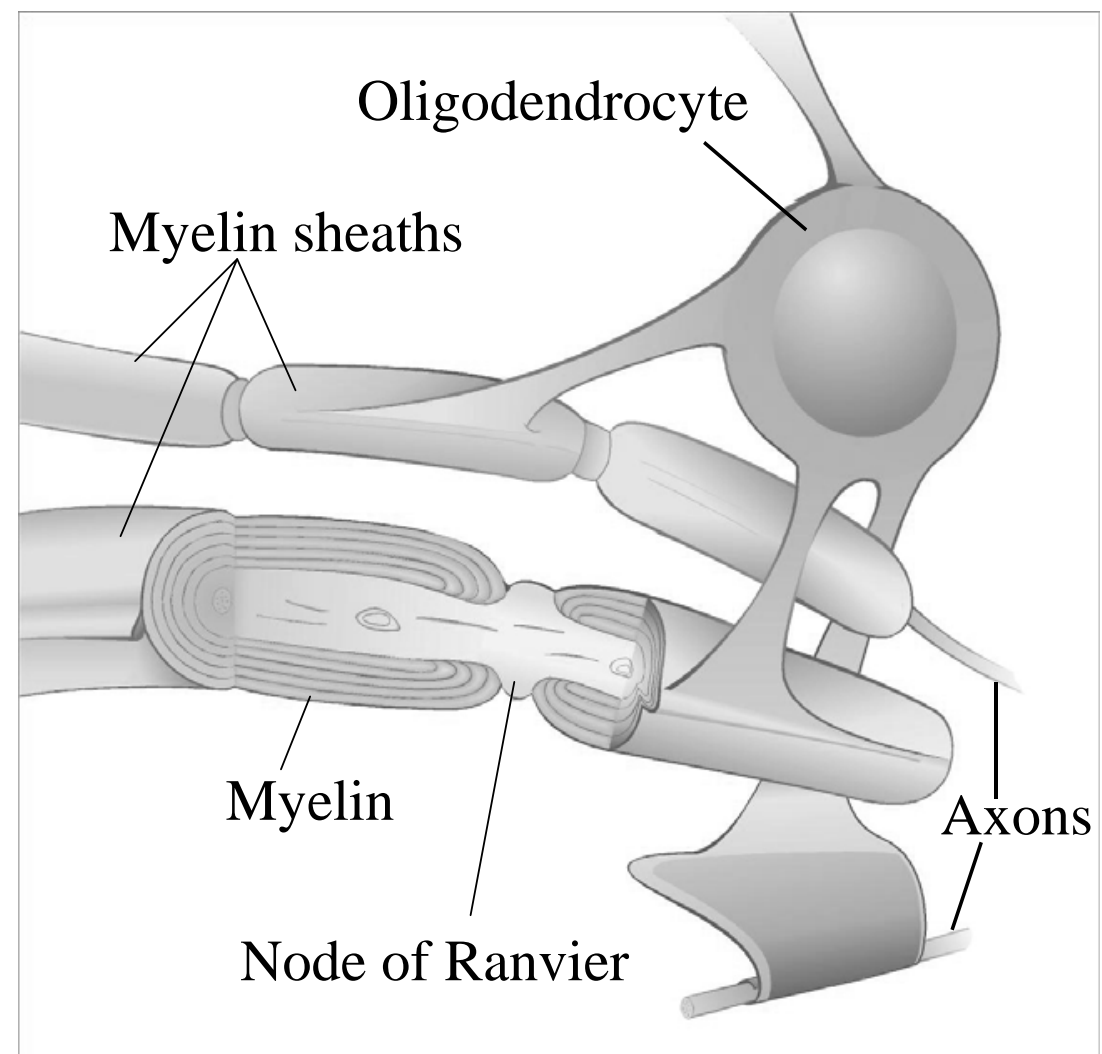

Figure 2 


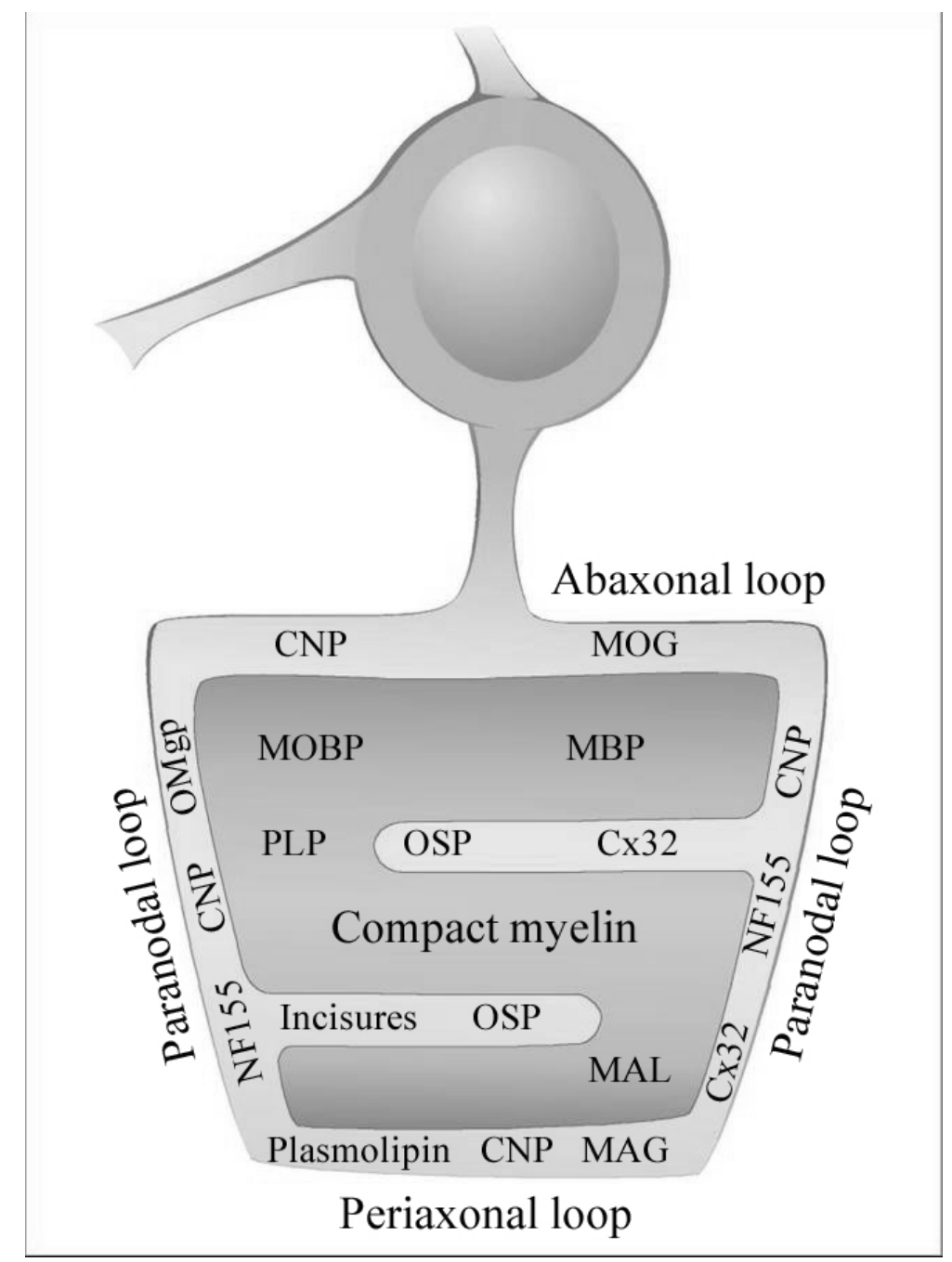

Figure 3 


\section{FIGURE LEGENDS}

Figure 1: Schematic representation of the morphological and antigenic characteristics of cells of the oligodendroglial lineage differentiating from mitogenic progenitor cells to mature myelinating OLGs. Stage-specific markers are boxed. [Adapted from Baumann and Pham-Dinh, 2001; Maier et al., 2005]

GD3: ganglioside GD3; NG2: NG2 chondroitin sulfate proteoglycan with a core protein of $260 \mathrm{kDa}$; A2B5: A2B5 mAb recognizes several gangliosides such as GT3; O4: O4 mAb reacts with sulfatides and still unidentified glycolipids; RIP: receptorinteracting protein.

Figure 2: Schematic representation of a myelinating OLG.

Figure 3: The myelin sheath is segregated in different subdomains with unequal protein and lipid distribution. [Adapted from Kim and Pfeiffer, 1999; Krämer et al., 2001] 